\title{
Blood Pressure Regulation in Stress: Focus on Nitric Oxide-Dependent Mechanisms
}

\author{
A. PUZSEROVA ${ }^{1}$, I. BERNATOVA ${ }^{1}$ \\ ${ }^{1}$ Institute of Normal and Pathological Physiology, Slovak Academy of Sciences, Bratislava, Slovak \\ Republic
}

Received August 24, 2016

Accepted September 5, 2016

\section{Summary}

Stress is considered a risk factor associated with the development of various civilization diseases including cardiovascular diseases, malignant tumors and mental disorders. Research investigating mechanisms involved in stress-induced hypertension have attracted much attention of physicians and researchers, however, there are still ambiguous results concerning a causal relationship between stress and long-term elevation of blood pressure (BP). Several studies have observed that mechanisms involved in the development of stress-induced hypertension include increased activity of sympathetic nervous system (SNS), glucocorticoid (GC) overload and altered endothelial function including decreased nitric oxide (NO) bioavailability. Nitric oxide is well known neurotransmitter, neuromodulator and vasodilator involved in regulation of neuroendocrine mechanisms and cardiovascular responses to stressors. Thus NO plays a crucial role in the regulation of the stress systems and thereby in the BP regulation in stress. Elevated NO synthesis, especially in the initial phase of stress, may be considered a stress-limiting mechanism, facilitating the recovery from stress to the resting levels via attenuation of both GC release and SNS activity as well as by increased NO-dependent vasorelaxation. On the other hand, reduced levels of NO were observed in the later phases of stress and in subjects with genetic predisposition to hypertension, irrespectively, in which reduced NO bioavailability may account for disruption of NO-mediated BP regulatory mechanisms and accentuated SNS and GC effects. This review summarizes current knowledge on the role of stress in development of hypertension with a special focus on the interactions among NO and other biological systems affecting blood pressure and vascular function.

\section{Key words}

Chronic stress • Endothelial dysfunction • Glucocorticoids • HPA axis • Hypertension

\section{Corresponding author}

A. Puzserova, Institute of Normal and Pathological Physiology, Slovak Academy of Sciences, Sienkiewiczova 1, 81371 Bratislava, Slovak Republic. E-mail: angelika.puzserova@savba.sk

\section{Introduction}

Stress is considered a risk factor associated with the development of various chronic diseases including cardiovascular diseases (CVDs), mental disorders, malignant tumors, diabetes mellitus, obesity, metabolic syndrome, inflammatory and autoimmune disorders and others. Although many different types of stressors exist, psychosocial stressors are apparently the most powerful and exert profound effects on the cardiovascular system (CVS) in humans (Esch et al. 2002a). At present stress represents one of the substantial risk factors that modern civilization brings to any society, therefore it has become a public health issue (Franco et al. 2003).

Research investigating mechanisms involved in stress-related diseases and pathophysiological changes have attracted much attention of physicians and researchers. However, despite their effort there are still ambiguous results concerning a causal relationship between stress and hypertension.

Although there are numerous definitions of stress, in medicine stress refers to a set of bodily reactions to external and internal factors, e.g. physical, 
psychological, metabolic, infectious and other, which are capable of disturbing homeostasis (Franco et al. 2003). In short, biological stress is an organism's response to a stress-provoking stimulus - stressor. Despite the wellknown theory of the general adaptation syndrome and Selye's doctrine of non-specificity (Selye 1936, Selye 1950), marked heterogeneity of neuroendocrine responses to various stressors was shown, suggesting the existence of stressor-specific neurochemical response patterns, depending on the nature (physical, biological, psychosocial), intensity and duration of stressor (Jezova et al. 1995, Kvetnanský et al. 1998, Pacak et al. 1998, Pacák and Palkovits 2001). Thus various stressors may trigger very different biological responses leading to variety of physiological, psychological and behavioral changes and stress-related somatic symptoms. Mravec et al. (2009) hypothesized that genetic basis might predispose some individuals to the development of stressinduced diseases due to altered interactions among nervous, endocrine, and immune systems. In human beings, personality, knowledge and previous skills are the other factors affecting the perception of stressor and its health impact (Keller et al. 2012). Therefore it is difficult to compare data from various animal stress models or selected human populations. Clinical research on stressrelated health consequences is difficult, because there are problems associated with the use of the term "stress", since we have no academic consensus on the definition of stress and subsequently no "standardized stress test" (Ohlin et al. 2004, Hovsepian et al. 2015). Animal models provide an opportunity to test the role of various stressors in cardiovascular and other diseases and to reveal the mechanisms by which the effects of such stressors are mediated.

Activation of the sympathetic division of autonomic nervous system and hypothalamic-pituitaryadrenocortical (HPA) axis (i.e. corticotropin releasing hormone - $\mathrm{CRH}$, adrenocorticotropic hormone - ACTH and glucocorticoids) are main characteristics of the stress response (Esch et al. 2002a, Golbidi et al. 2015). These systems promote adaptation to challenges, a process called "allostasis", meaning the process of maintaining stability (homeostasis) despite the change. Nevertheless, these allostatic/adaptive systems also cause problems for the body if their function is inadequate or excessive (McEwen 1998, McEwen 2007). Thus, the organism aims to achieve new stability (allostasis) in new conditions by changes in physiological and behavioral responses (McEwen 2007). However, when stressors are too frequent, long-lasting and/or too intensive, the resulting allostatic load can lead to various diseased states, including hypertension (Fig. 1). On the other hand, the intensity of the stress reaction is determined by the relationship between the activation of the stress systems (mainly sympathetic nervous system, HPA axis) and "stress-limiting systems", which may restrict the excessive activation of the stress systems and, thereby, the detrimental effect of stress. Malyshev and Manukhina (1998) suggested that the system of nitric oxide (NO) generation is such a stress-limiting system, based on the capability of NO to limit key links of the stress reaction.

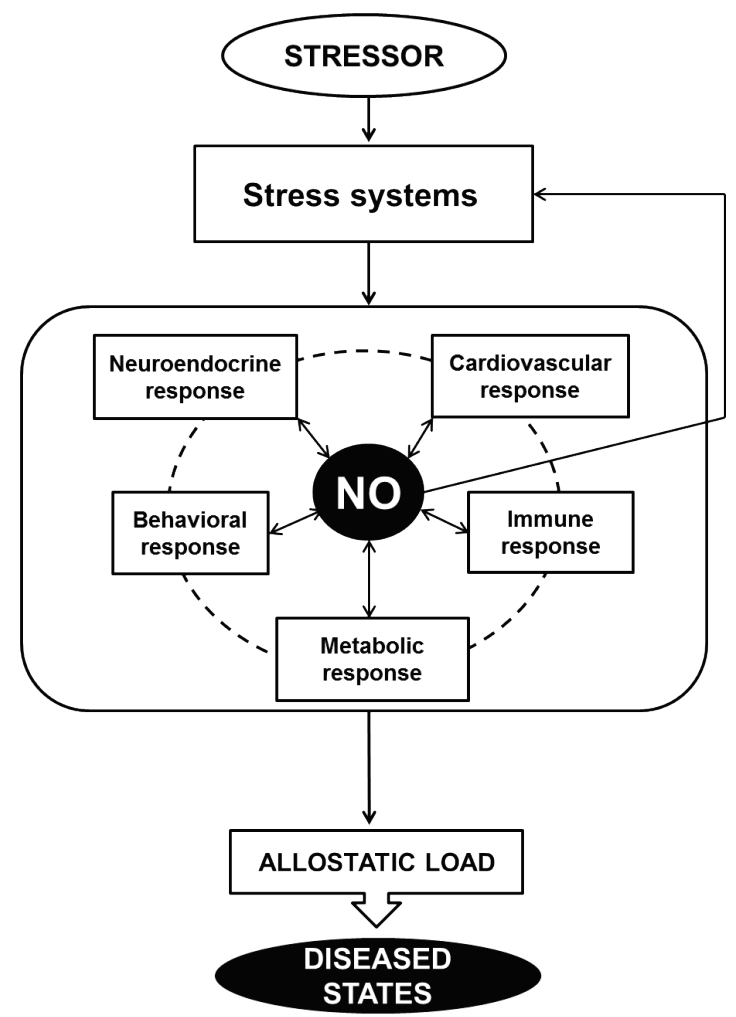

Fig. 1. After exposure to stressor, activation of stress systems leads to cascade of neuroendocrine, cardiovascular, behavioral, metabolic and immune responses, which all were shown to interact with nitric oxide (NO). NO is able to attenuate stress systems. Yet, if stressors are frequent, long-lasting and/or intensive, or if allostatic systems are overactive or underactive or fail to stop after the end of stressful event, the resultant allostatic load can lead to various diseased states.

Nitric oxide is a widespread biological mediator produced in various tissues by one of four isoforms of nitric oxide synthase (NOS: eNOS - endothelial, nNOS neuronal, iNOS - inducible, mtNOS - mitochondrial) (Guix et al. 2005) with the complex regulatory role in the organism. Nitric oxide is well-known neurotransmitter and neuromodulator, significant NO production was 
determined in various parts of the central and peripheral nervous system (Steinert et al. 2010), vasculature and heart (Pechanova et al. 2015) as well as other tissues and organs (Villanueva and Giulivi 2010). NO was shown to be implicated in modulation of responses to stressors suggesting its regulatory role in stress (Malyshev and Manukhina 1998, Bondarenko et al. 2001, Esch et al. 2002b, Gulati et al. 2006, Stefano et al. 2006, Gulati et al. 2015). Moreover, significant progress was achieved in the characterization of the role of NO as an endotheliumderived relaxing factor in various pathological states, including hypertension. Reduced NO bioavailability is implicated in various experimental models of hypertension as well as in human primary and secondary hypertension (Panza et al. 1993, Taddei et al. 1998, Ghiadoni et al. 2012, Bernatova 2014, Pechanova et al. 2015). Yet the exact pathways implicated in the interaction of NO with the mechanisms involved in stress reaction and its contribution to the development of stressinduced hypertension and other CVDs are still matter of experimental research.

At the present time, it is well recognized that stress and NO play an important role in the pathogenesis of CVDs. Acute coronary syndromes (including unstable angina pectoris, myocardial infarction and sudden cardiac death), arrhythmias, stroke (ischemic, hemorrhagic) or transient ischemic attack and stress (Takotsubo) cardiomyopathy are cardiovascular events that may be triggered by acute physical and psychosocial stressors and their impact may be more significant in individuals at high cardiovascular risk (Willich et al. 1994, Kirkup and Merrick 2003, Kloner 2004, Wittstein et al. 2005, Wilbert-Lampen et al. 2008, Steptoe and Brydon 2009, Nalivaiko 2011, Mostofsky et al. 2012, Schwartz et al. 2012, Struzkova et al. 2014, Y-Hassan et al. 2015, Barbaryan et al. 2016). In addition, chronic stress is considered a significant risk factor of CVDs (Rozanski et al. 1999, André-Petersson et al. 2001, Esch et al. 2002a, Franco et al. 2003, Ohlin et al. 2004, Steptoe and Kivimäki 2013). There is also a growing body of evidence that psychosocial stressors have an important role in the genesis, onset, progression and manifestation of CVDs (Kaplan et al. 1982, Kaplan et al. 1983, Manuck et al. 1986, Strawn et al. 1991, Diez-Roux et al. 1995, Helminen et al. 1995, Cagan et al. 1999, Rozanski et al. 1999, Franco et al. 2003, Ohlin et al. 2004, Toda and Nakanishi-Toda 2011, Golbidi et al. 2015). The Interheart case-control study from 52 countries showed that the presence of psychosocial stressors (stress at work and home, financial stress and major life events in the past year) is associated with increased risk of acute myocardial infarction, which was consistent across regions, in different ethnic groups, and in men and women (Rosengren et al. 2004).

There is also evidence that acute and chronic stress can induce endothelial injury and dysfunction. The endothelium regulates vascular tone, circulation of blood cells, inflammation and hemostasis. Endothelial dysfunction is considered an early sign of atherosclerosis and early predictor of future cardiovascular events (Daiber et al. 2016). CVDs are usually multifactorial and characterized by the presence of one or more risk factors, such as tobacco use, harmful use of alcohol, unhealthy diet and obesity, physical inactivity or sedentary lifestyle, hypertension, diabetes mellitus and dyslipidemia (WHO 2015). Interestingly, all of above mentioned risk factors of CVDs can be associated with stress and endothelial dysfunction (Rozanski et al. 1999, Favero et al. 2014, WHF 2015, Golbidi et al. 2015). Endothelial dysfunction can thus mediate the adverse influence of stressors on cardiovascular health.

Despite many experimental and populationbased observational studies, there is still conflicting information about the causal relation between stress and hypertension as studies investigating the effects of chronic stress on blood pressure (BP) produced ambiguous results (Esler et al. 2008, Sparrenberger et al. 2008). Despite the available data suggesting that chronic stress contributes to the development of hypertension (Timio et al. 2001, Pickering 2004, Spruill 2010), the results of experimental studies focused on the mechanisms involved in stress-induced hypertension are inconsistent, yielding both positive and negative evidence on the participation of stress in the development of hypertension (Bobrovskaya et al. 2013, Crestani 2016).

This review, though not exhausting, summarizes current knowledge on the role of stress in development of hypertension with a special focus on the interactions among NO and other BP-regulatory systems involved in stress reaction.

\section{Nitric oxide and blood pressure: involvement of eNOS, nNOS and iNOS}

Nitric oxide is well known as the most potent vasodilating substance (endothelium-derived relaxing factor), which (besides its other functions) participates in modulation of vascular resistance and heart function and 
thus in BP regulation (Török and Gerova 1996, Kunes et al. 2004). NO is also involved in stress physiology and stress-related disease processes (Esch et al. 2002b, Gulati et al. 2006).

The role of NO in CVS was investigated mainly in the model of NO-deficient hypertension, in which NO production was inhibited by $\mathrm{N}^{\mathrm{G}}$-nitro-L-arginine methyl ester (L-NAME), which non-specifically inhibits all NOS isoforms (Víteček et al. 2012). Using this model we have shown that chronic pharmacological attenuation of NO synthesis resulted in metabolic alterations and hypertension (Bernatova et al. 1996), reduced vasorelaxation and elevated vasoconstriction (Holécyová et al. 1996, Bernatova et al. 2002b, Pechanova et al. 2004a) and arterial wall thickening and myocardial fibrosis (Babal et al. 1997) in normotensive rats. Moreover, hypertension induced by chronic NOS inhibition in rats seems to be sustained due to interaction of several mechanisms, including the activation of the sympathetic nervous system (including sympatho-adrenomedullary part) and the reninangiotensin system (Sander et al. 1995, Zanchi et al. 1995, Kvetnansky et al. 1997, Gerová et al. 2004, Pechanova et al. 2004b, Zicha et al. 2006, Vargas et al. 2007, Zicha et al. 2009, Behuliak et al. 2011, Paulis et al. 2012). Rats subjected to chronic administration of L-NAME are thus a useful experimental tool to study the induction and progression of NO deficiency-mediated endothelial dysfunction and hypertension.

On the other hand, mild increase of $\mathrm{NO}$ production in the CVS may represent protective mechanism against hypertension, cardiac and vascular remodeling and thus may be involved in cardiovascular protection. Various antioxidants and natural polyphenols, including these isolated from red wine and cocoa were shown to activate NO production and to reduce BP (Bernatova et al. 2002b, Pechanova et al. 2004a, Galleano et al. 2013). Interestingly, we have shown that chronic administration of a low dose of L-NAME can increase NO production in the aorta and left heart ventricle and improve endothelium-dependent vasorelaxation in rats (Bernatova et al. 2010) supposedly via the negative feedback regulation of NOS (Kopincova et al. 2012).

In contrast to chronic L-NAME treatment, chronic administration of structurally different NOS inhibitor, 7-nitroindazole (7-NI), failed to affect BP in normotensive Wistar and spontaneously hypertensive rats (SHR) (Cacanyiova et al. 2012, Cacanyiova et al. 2014, Kristek et al. 2015). Moreover, chronic L-NAME administration inhibited endothelium-dependent relaxation of the thoracic aorta, whereas it remained unchanged after chronic 7-NI treatment in Wistar and SHR rats (Cacanyiova et al. 2012, Cacanyiova et al. 2014). In addition, neurogenic contractions (induced by transmural nerve stimulation of nerve endings and mediated by endogenous noradrenaline) in mesenteric artery remained unchanged after 7-NI-treatment, but increased after L-NAME-treatment (Cacanyiova et al. 2012, Cacanyiova et al. 2014). As 7-NI is believed to inhibit predominantly nNOS (Gulati et al. 2006, Cacanyiova et al. 2014), the roles of eNOS-derived NO and nNOS-derived NO in BP regulation seem to be different. However, it has to be noted that despite enormous effort of researchers to find the substances which would be absolutely specific for either nNOS or eNOS, which would allow us to distinguish NO produced by nNOS from NO produced by eNOS under chronic in vivo conditions, are still not available (Alderton et al. 2001, Víteček et al. 2012). Thus, in contrast to the relatively well-known role of eNOS in BP control, the role of NO produced by the nNOS remains unclear.

Regarding iNOS, excessive amounts of NO produced by this isoform can promote nitrosative stress and endothelial dysfunction. Indeed, Leo et al. (2015) showed that L-NAME-mediated inhibition of eNOS was only partially responsible for the vascular pathology observed in this model. Secondary effects of L-NAME treatment may include an increase in iNOS-produced NO and peroxynitrite formation, which may be an important factor for the progression of vascular dysfunction in L-NAME-induced hypertension (Pechanova et al. 2004b, Leo et al. 2015). Nevertheless, different roles of individual NOS isoforms in BP regulation are supported by the findings in NOS knock-out mice. Functional and morphological alterations observed in L-NAME-induced hypertension (Babal et al. 1997) were similar to those observed in mice, in which three NOS isoforms were disrupted, i.e. $\mathrm{n} / \mathrm{i} / \mathrm{eNOS}^{-/-}$(Tsutsui et al. 2010). Moreover, studies that used triple NOS disrupted $\left(\mathrm{n} / \mathrm{i} / \mathrm{eNOS}^{-/}\right)$mice showed that the magnitude of hypertension in the triply $\mathrm{NOS}^{-/-}$disrupted mice were similar to that in mice with the eNOS gene disrupted singly $\left(\mathrm{eNOS}^{-/}\right)$or doubly $\left(\mathrm{n} / \mathrm{eNOS}^{-/-}\right.$or $\left.\mathrm{i} / \mathrm{eNOS}^{-/}\right)$(Morishita et al. 2005). Furthermore, nNOS knock-out mice did not develop hypertension (Sällström et al. 2008). Finally, BP of iNOS $^{-/-}$mice did not differ from wild type mice in late adulthood (Ihrig et al. 2001). Taken together, these studies suggest that hypertension is a common characteristic of the lack of eNOS-produced NO. 


\section{Effect of stress on blood pressure}

Researchers investigating the regulation of BP during stress have been primarily focused on acute stress. As far as the acute cardiovascular responses to stressors are concerned, the changes of heart rate (HR), BP, cardiac output as well as skin and skeletal muscle blood flow can occur (Lacy et al. 1995, Muller et al. 2001, Kellerová 2013, Garafova et al. 2014). Cardiac output and systemic vascular resistance are the major effector components of neural BP regulation (Grassi and Ram 2016). It is known that acute stress is capable to increase immediately the arterial BP, which is mediated either by an increase in cardiac output or an increase in systemic vascular resistance (Rozanski et al. 1988, Lacy et al. 1995, Esch et al. 2002a, Kellerová 2013). It was shown that men at the high risk for development of hypertension had significantly higher BP accompanied by higher vascular resistance during mental stress compared to low risk subjects. The high and low risk groups had negligible differences in HR, stroke volume, and cardiac output after the exposure to mental stress. This pattern of results implicates vascular resistance as the dominant element in altered BP control in young men at high risk for hypertension (Marrero et al. 1997). Importantly, it has been shown that the cardiovascular component of the stress reaction does not require extreme stressors as the increase of BP was evident in daily life already with trivial stimuli, such as watching television (Kellerová 2013, Regecová and Kellerová 2015).

While the role of the brain and the elevated activity of sympathetic nervous system (SNS) in the etiopathogenesis of essential hypertension is widely accepted, the role of stress in the genesis and progression of hypertension and the exact biological mechanisms involved are ambiguous. Prolonged, frequent or repeated exposure to stressors can lead to autonomic nervous system dysregulation and to the changes in the HPA axis and augmented hormone release from the adrenal glands (Golbidi et al. 2015). All these changes can lead to cardiovascular dysregulation (see also Fig. 2). Interestingly, the findings of Bobrovskaya et al. (2013) suggest that stressors not only alter the BP regulation during the exposure but these alterations persist well beyond the duration of stressor action. Furthermore, the study of Muller et al. (2001) suggests a sustained effect of chronic stress on arterial BP regulation after the end of stress.

Several epidemiological studies have demonstrated that individuals chronically exposed to stressful life events and psychosocial stress frequently exhibit persistent hypertension (Timio et al. 2001, Pickering 2004). Esler et al. (2008) concluded that chronic mental stress is a cause of essential hypertension in humans. On the other hand, Sparrenberger et al. (2008) found that recent stressful life events and current psychological distress were not associated with hypertension.

According to Kellerová (2013), psychosocial factors play a permissive role in high BP development. Road traffic noise is a frequent, unavoidable, persistent and continuously increasing environmental stressor to which people are exposed already in the early childhood. Preschool children, attending kindergartens situated in areas with high urban traffic noise, had higher mean systolic and diastolic BP than children in quiet areas (Regecová and Kellerová 1995). In the given study, medium- and high-level urban traffic noise was associated with higher incidence of BP values above the respective 95 th percentiles in preschool children. It was also shown that chronic stressful events in early life increase the risk of elevated BP in late adulthood (Alastalo et al. 2013). Interestingly, Kellerová (1993, 2013) found that there is a greater increase of systolic and diastolic BP and of HR during bottle feeding than during breast feeding in human neonates, suggesting the protective role of positive emotions. Thus feeding profile may also play a role in early programming of cardiovascular changes.

Several animal studies, which have examined the impact of chronic stress on BP, yielded contradictory results. In normotensive rats, a chronic multiple stress paradigm produced by series of mild, unpredictable stressors elevated resting HR, decreased HR variability, and exaggerated pressor and HR responses to acute air jet stress, but did not lead to sustained increase of mean arterial pressure (MAP) in male Sprague-Dawley (SD) rats (Grippo et al. 2002). In normotensive mice exposed to 7-day intermittent shaker stress, significant elevations of MAP and HR were recorded during each shaking session with important circadian changes in pressor responsiveness, but there was no sustained increase of MAP (Bernatova et al. 2002a). Another study in mice showed that psychosocial stress produced by crowding induced sustained hypertension (Henry and StephensLarson 1984). In contrast, Harrap et al. (1984) observed no development of hypertension in normotensive WistarKyoto (WKY) and SD rats subjected to crowding and 
isolation stress, respectively. A social stress paradigm, in which normotensive male Wistar and Long-Evans rats were housed with different females, produced no change in basal BP or its circadian rhythm (Lemaire and Mormede 1995). Yet chronic stress produced by social instability due to mixing males from different colonies resulted in hypertension in Long-Evans but not in WKY and SD rats (Henry et al. 1993). On the other hand, chronic exposure to various stressors caused elevation of MAP in SD rats (Muller et al. 2001). Chronic continuous light exposure (24 h/day), which can be considered a potent stressor, leads to increase in systolic BP in Wistar rats (Simko et al. 2010, Repová-Bednárová et al. 2013, Simko et al. 2014). In addition, in Wistar rats exposed to continuous light, the light-induced increase in sympathetic outflow can suppress BP circadian rhythm (Briaud et al. 2004). Other stressor, chronic cold exposure, can induce hypertension in SD, but not in Long-Evans rats (Riesselmann et al. 1992). Chronic noise stress caused significant increase in HR and MAP in adult male Wistar rats (Said and El-Gohary 2016). Six weeks of inescapable unpredictable electrical footshocks in adult male Wistar rats significantly reduced body weight gain, locomotor activity and social interaction time (symptoms commonly induced by chronic stress and depression in humans) and were associated with elevation of systolic BP and pulse pressure and modifications in sympathoadrenal pathways (Bobrovskaya et al. 2013). Sustained MAP elevation was reported after chronic stress in male SD rats that responded to acute stressor via elevated systemic vascular resistance, i.e. in vascular responders, but not in responders responding by an increase in cardiac output (Muller et al. 2001). The development of hypertension and cardiac pathology such as cardiac fibrosis or coronary vascular wall hypertrophy were observed in young 4-week-old normotensive rats exposed to chronic isolation followed by territorial stress or exposed to territorial stress alone (Andrews et al. 2003).

Several studies demonstrated the importance of genetic background in stress-induced pressor responses in rats with various family history of hypertension (Fisher and Tucker 1991, Hatton et al. 1993, Tucker and Hunt 1993, Li et al. 1997, Mansi and Drolet 1997, McDougall et al. 2000) suggesting that positive family history of hypertension may be an important factor in the development of stress-induced hypertension. Thus, normotensive animal models, without family history of hypertension, need not be always appropriate tools for investigation of stress/hypertension association. For such studies, a more suitable model - borderline hypertensive rats (BHR) - with a family history of hypertension is produced by the mating of spontaneously hypertensive dams (or sires) with normotensive sires (or dams) (Lawler et al. 1980, Sanders and Lawler 1992, Šarenac et al. 2011, Zemančíková and Török 2015). The advantage of this model is that BHR are more sensitive to behavioral stress than normotensive rats and they do not develop severe age-related hypertension as do SHR rats. BHR exhibit various cardiovascular abnormalities like myocardial hypertrophy, sympathetic hyperresponsiveness (demonstrated by tachycardia and high sensitivity of arterial contractile responses to noradrenergic stimulation) and endothelial dysfunction in various arteries (Puzserova et al. 2013a, Zemančíková and Török 2015). These findings support the idea that in BHR the increased BP level (as compared to WKY rats) is associated with a higher sympathetic activity. The use of chronic psychosocial models of stress in BHR resulted in the development of hypertension, heart hypertrophy and significant cardiac pathology (Lawler et al. 1981, Sanders et al. 1989). Our studies also point to genotype-related differences in stress-induced pressor responses in young female and male rats as well as in adult male rats (Bernatova et al. 2007a, Slezak et al. 2014, Bernatova et al. 2015). In our studies, chronic crowding stress applied in young BHR and SHR females during sensitive BP developmental window (i.e. at the age of 5-7 weeks) (Zicha and Kunes 1999) led to the acceleration of BP increase in BHR, but not in age-matched WKY and SHR, in which genetic predisposition to hypertension was a predominant factor in development of BP in young age (Slezak et al. 2014). Thus young BHR rats were more vulnerable to stress than the offspring of two normotensive or two hypertensive parents. These studies showed that the exposure of genetically predisposed subjects to stress, especially in a sensitive developmental period of life, can trigger the onset of hypertension development to earlier periods of life.

In adult male rats, chronic crowding resulted in a significant increase of BP in SHR-mothered BHR and SHR compared to controls but not in Wistar, WKY and Wistar-mothered BHR (Puzserova et al. 2006, Bernatova et al. 2007a). However, in some studies even a chronic stress exposure of BHR (aggregation or social instability) failed to result in stress-induced hypertension, although typical signs of stress such as reduced weight gain, adrenal hypertrophy, elevation of plasma noradrenaline 
(NA) and increase of left and right heart ventricle mass were observed (Harrap et al. 1984, Gelsema et al. 1994, Lemaire and Mormede 1995). Similarly, ten days of air-jet stress $(2 \mathrm{~h} /$ day $)$ failed to increase the baseline values of MAP and HR in male BHR and WKY rats aged 14-16 weeks (Fuchs et al. 1998). However, these authors found that changes in vascular reactivity induced by stress appear to correlate with, and may contribute to, the different hemodynamic adaptations to repeated stressors observed in WKY and BHR rats.

Finally, various factors that potentially contribute to controversial results of above mentioned animal studies may include different type of stressors, the duration of their action, the animal's age, sex and strain as well as the method used to assess arterial BP (Nalivaiko 2011).

\section{Endothelial function in stress}

Nervous, humoral and endothelial vasomotor controls are important factors in systemic cardiovascular homeostasis and BP regulation (Gerová 2000, Kellerová 2013, Bernatova 2014). As mentioned above, endothelium regulates vascular tone, i.e. influences the contractile activity of vascular smooth muscle by releasing contracting factors (EDCFs - endotheliumderived contracting factors) such as endothelin-1 or angiotensin II and relaxing factors (EDRFs endothelium-derived relaxing factors) such as NO, prostacyclin $\left(\mathrm{PGI}_{2}\right)$, hydrogen sulfide $\left(\mathrm{H}_{2} \mathrm{~S}\right)$ and endothelium-derived hyperpolarizing factor(s) (EDHFs). In addition, the endothelium regulates the proliferation/ growth of the underlying smooth muscle, and also acts as a barrier to control the exchange of nutrients, biomolecules and messengers between the blood and surrounding tissues. The EDRFs also possess antiaggregatory properties and suppress thrombus formation (Daiber et al. 2016). Endothelial dysfunction, which includes an impairment of endothelium-dependent vasorelaxation (Bernatova 2014), is associated with various CVDs, including hypertension. Although the involvement of alterations in endothelium-derived $\mathrm{NO}$ in stress-related hypertension is not clearly defined, there are both animal and human studies showing the involvement of peripheral vascular changes in this particular type of hypertension.

Acute exposure to stressors influences vasomotion in different vascular beds. In humans, blood flow redistribution occurs from the visceral and cutaneous beds toward the skeletal and heart muscle vasculature during acute stress, which is mediated mainly by vasoconstriction in the splanchnic, renal and cutaneous vascular beds and by vasodilatation of the muscle vasculature (Kellerová 2013, Crestani 2016).

In healthy volunteers elevated forearm blood flow, specifically endothelial NO-mediated, was observed after acute mental stress (Dietz et al. 1994). Similarly, Carter et al. (2005) found mental stress induced forearm vasodilatation, which was not associated with changes in muscle sympathetic outflow. The involvement of local NO release in the forearm vasodilator response to acute mental stress in humans was detected by Cardillo et al. (1997). Interestingly, acute psychological and physical stress transiently enhances brachial artery flow-mediated dilation stimulated by exercise in healthy men (Szijgyarto et al. 2014).

In contrast, there are studies showing that brief episodes of mental stress induced endothelial dysfunction in both brachial and radial arteries of healthy subjects without cardiovascular risk factors (Ghiadoni et al. 2000, Spieker et al. 2002). Spieker et al. (2002) showed that mental stress lasting $3 \mathrm{~min}$ induced a prolonged endothelial dysfunction, which was prevented by selective endothelin-A receptor antagonism in healthy subjects without cardiovascular risk factors. Similarly, mental stress induced reduction of brachial artery flowmediated endothelium-dependent dilation in subjects with metabolic syndrome (Sales et al. 2014). In patients with essential hypertension and with chronic myocardial infarction an abnormal vasomotor reactivity was induced by acute emotional stress, suggesting the presence of endothelial dysfunction (Kellerová 2013). In addition, acute mental stress can trigger transient myocardial ischemia, often silent, in patients with coronary artery disease (Rozanski et al. 1988). Furthermore, increased sympathetic tone induced by mental stress can cause acute coronary vasoconstriction (instead of vasodilatation) also in patients without angiographically demonstrable coronary artery disease (Lacy et al. 1995). Together, these studies suggest that short episodes of stressor exposure, similar to those encountered in everyday life, may cause transient endothelial dysfunction also in healthy young individuals and the presence of endothelial dysfunction and atherosclerotic plaques may result in abnormal vascular reactivity to stressors. However, the exact mechanisms which impair endothelial function in stress are still not clearly defined.

Animal studies revealed several mechanisms that 
are involved in the disruption of endothelial function in stress. Short-term social stress caused an increase in HR and a damage of the endothelium in the thoracic aorta and coronary artery in monkeys, which was prevented by the treatment with $\beta$-adrenergic blocking agent metoprolol (Strawn et al. 1991). Williams et al. (1993) suggested that repeated episodes of acute sympathetic stimulation result in sharp increases of $\mathrm{BP}$ and $\mathrm{HR}$, which may damage the vascular endothelium and impair the release or augment the breakdown of NO. Signs of endothelial injury, rise in endothelemia and von Willebrand factor concentrations, were also observed early after acute immobilization stress in adult male (Jezova et al. 2003) and female SD rats (Kristova et al. 2006). Thus vascular damage, including changes in endothelial function, can occur before the development of hypertension (Fuchs et al. 1998) and may accelerate its onset.

Regarding chronic stress, little information is available on its impact on endothelial function in humans because of methodological and ethical limitations. More information on the mechanisms involved in altered vascular function during chronic stress is available from experimental studies in monkeys and rodents.

Chronic psychosocial stress in monkeys impaired endothelium-mediated dilatation of coronary arteries (Williams et al. 1991). In addition, chronic psychosocial stress reduced receptor-mediated release of NO by acetylcholine (ACh), non-receptor-mediated release of NO by the calcium ionophore A23187, without changes in endothelium-independent NO-mediated vasorelaxation to nitroprusside in the iliac arteries isolated from monkeys fed with atherogenic diet (Williams et al. 1993). Reduced endothelium-dependent relaxation to ACh was observed in the aorta of socially isolated female prairie voles (Peuler et al. 2012). Similar finding was observed in the thoracic aortas of male mice subjected to unpredictable chronic mild stress (Insingrini et al. 2011). Neves et al. (2009) also found that chronic unpredictable stress induces functional changes in the aorta of male SD rats which may be related to decreased NO bioavailability. These studies suggest that chronic stress may downregulate NO production and/or bioavailability. The impairment of NO production in long-term stress may result from sudden and repeated pressure fluctuation (Fokkema et al. 1986) that could damage the endothelial monolayer and alter the vascular wall structure. In Wistar-mothered BHR, electron microscopy showed that chronic crowding-induced injury of endothelial cells in the aorta is characterized by mitochondrial damage, presence of vacuoles, increased number of lysosomes, Weibel-Palade bodies, changes of intercellular connections and local disruption of endothelium, while only slight changes were seen in Wistar rats (Okruhlicova et al. 2008). This might also result from the fact that connexin 43 expression was reduced in the aortic endothelium already in prehypertensive period, which may affect cell-to-cell communication and thus participate in acceleration of hypertensive disease in stress in genetically predisposed rats (Dlugosova et al. 2008). These results suggest increased vulnerability of endothelium of rats with genetic predisposition to hypertension to stress-induced damage that may contribute to acceleration of arterial dysfunction and hypertension development following stress.

Regarding the functional endothelial changes, most of the studies investigated total endotheliumdependent vasorelaxation and did not take into account individual components of vasodilatation mediated by different EDRFs. Thus, it remains unclear, if chronic stress might impair endothelium-mediated dilation only due to reduced bioavailability of NO. Furthermore, it is unknown if the effects of stress on endothelial function can be reversed by removing the stressor. However, Williams et al. (1993) found that previous chronic stress lasting 18 months did not have persisting effects on endothelium-dependent NO-mediated dilatation after 18 months of stress. The same authors also found that the deleterious effect of psychosocial stress on endotheliummediated dilation was not mediated through the products of the cyclooxygenase (COX) pathway. Peuler et al. (2012) observed that chronic social isolation caused an enhancement of ACh-induced contraction in nonprecontracted endothelium-intact aortae. Such an enhancement of ACh-induced contraction suggests abnormally excessive release of EDCFs from the endothelium. The excessive release of EDCFs, mainly COX-dependent, has been demonstrated repeatedly in arteries of hypertensive rats and humans (Paulis et al. 2008, Virdis et al. 2010, Líšková et al. 2011, Vanhoutte 2011, Puzserova et al. 2013a, Puzserova et al. 2014). EDCFs can effectively counteract the endotheliumdependent vasorelaxation, including its NO-mediated component (Dai et al. 1992). In addition, EDCFs contribute to NA-induced contractions and this effect is enhanced in conduit arteries of SHR (Líšková et al. 2011). Moreover, acute NOS inhibition enhanced the contribution of EDCFs to NA-induced contraction 
(Lišková et al. 2011). The contractile hyperreactivity to angiotensin II in carotid artery of acutely restrained diabetic rat is also mediated by metabolites derived from COX-2, highlighting the harmful role of acute stress in modulation of diabetic vascular complications (Moreira et al. 2015). These results show that the impairment of the interplay between NO, EDCFs and NA is an important mechanism which may be involved in stresslinked hypertension.

On the other hand, there are reports of opposite endothelial responses induced by chronic stress. Increased endothelium-dependent vasodilator responses of the aorta were observed in mice made hypertensive by the exposure to chronic social stress in a complex population cage (Webb et al. 1987). Similar findings were observed also in male Wistar rats submitted to chronic immobilization stress (Bruder-Nascimento et al. 2015). Chies et al. (2003) reported that chronic forced swimming stress may increase non-endothelial NO activity in both the aorta and superior mesenteric artery of adult male Wistar rats. In male Wistar rats the vascular adaptive response to chronic and acute stress was characterized by hyperactivity of the endothelial L-arginine/NO system (Cordellini and Vassilieff 1998, Cordellini et al. 2006) and this adaptive response was impaired in SHR, independently of the hypertensive state (prehypertensive or hypertensive) (Cordellini et al. 2006). These findings indicate that chronic stress can promote adaptive vascular NO-dependent responses.

To elucidate the effect of chronic stress on NO-dependent component of relaxation, we used stress produced by crowding in rats. Crowding is a typical social stressor (Bugajski 1999, Gavrilovic and Dronjak 2006, Myslivecek and Kvetnansky 2006). In humans, crowded residents had higher levels of urinary catecholamines and greater increases in BP and HR during performance of a challenging task than uncrowded residents (Fleming et al. 1987), suggesting a deleterious effect of chronic crowding on cardiovascular regulation. Although crowding is a relatively mild stressor, it has a considerable effect on the HPA axis and the sympathoadrenomedullary system (SAS) in rats (Djordjevic et al. 2003, Dronjak et al. 2004).

In our studies, the effect of chronic social stress on endothelium-dependent vasorelaxation mediated by NO was tested in the femoral and mesenteric arteries. The functional status of the endothelium was tested by the $\mathrm{ACh}$ test in isolated preconstricted arteries. However, ACh-induced relaxation results from stimulated release of at least three different vasodilating agents released from the endothelial cells - NO, $\mathrm{PGI}_{2}$, and EDHFs (Puzserova et al. 2013a). Under the normal conditions, NO seems to be the most powerful vasorelaxing factor, however, the extent of NO-dependent relaxation depends on the size of the artery. The biggest NO dependency of endotheliumdependent relaxation was observed in the aorta, while the role of NO is much smaller in the small resistant arteries where EDHFs seem to be more important (Shimokawa et al. 1996). We observed increased endothelium-dependent ACh-induced relaxation and its NO-mediated component in the femoral artery of adult male WKY (Puzserova et al. 2006, Bernatova et al. 2007b, Puzserova and Bernatova 2010) and Wistar rats (Bernatova et al. 2007a) exposed to crowding for 8 weeks. Concurrently, a reduction of $\mathrm{NO}$-independent relaxation was found in the femoral artery from male WKY rats after 8-week crowding (Puzserova et al. 2013b). However, chronic crowding failed to alter endothelial function of the superior mesenteric artery and its first branches in adult male WKY rats (Puzserova et al. 2012). Interestingly, in the presence of the potent antioxidant, ascorbic acid, the elevated endothelium-dependent relaxation was found in the mesenteric arteries from stressed WKY rats (Bernatova et al. 2007b), suggesting an important role of reactive oxygen species (ROS). Furthermore, 2-week crowding elevated NO production and superoxide concentration in pubertal female WKY rats, which resulted in reduced NO-dependent relaxation of the femoral artery (Slezak et al. 2014).

Despite the fact that 8 -week crowding led to elevated NOS activity and nitrate/nitrite (stable NO metabolites - NOx) levels in the aorta of adult WKY male rats, stress failed to affect BP, HR and plasma NOx levels (Puzserova et al. 2006, Bernatova et al. 2007b, Puzserova and Bernatova 2010, Puzserova et al. 2013b). Interestingly, in male Wistar rats we observed only a tendency towards elevation of NOS activity in the aorta using the same stress model (Bernatova et al. 2007a, Bernatova et al. 2010). In addition, the treatment of Wistar rats with a low dose of L-NAME, which produced only temporal increase of BP, precluded the stressinduced enhancement of endothelium-dependent relaxation of the femoral artery and resulted in a gradual BP elevation (Bernatova et al. 2010).

The prolongation of crowding to 12 weeks in WKY rats still failed to increase BP, but resulted in a reduction of overall endothelium-mediated vasorelaxation of the femoral artery. This was still 
associated with elevated NOS activity in the aorta and elevated NO-dependent component of ACh-induced relaxation of the femoral artery. However, reduction of the NO-independent component (i.e. mediated by EDHFs and/or $\mathrm{PGI}_{2}$ ) of relaxation was observed also in these rats, which was more pronounced after 12-week vs. 8-week crowding (Puzserova et al. 2013b). Our findings indicate that extended crowding is associated with endothelial dysfunction and reduced NO-independent relaxation despite increased NO production. Similar findings were observed using 8-week mild stress in rats (Bouzinova et al. 2014). The authors found that NO-dependent relaxation and eNOS expression were increased in small mesenteric arteries from stressed anhedonic rats compared with the non-stressed rats. In addition, inhibition of COX activity revealed increased COX-2dependent relaxation in the anhedonic group. In contrast, eNOS-independent and COX-independent relaxation to $\mathrm{ACh}$, i.e. endothelium-dependent hyperpolarization-like component of relaxation, was reduced in stressed anhedonic rats, which was associated with decreased transcription of intermediate-conductance $\mathrm{Ca}^{2+}$-activated $\mathrm{K}^{+}$channels (Bouzinova et al. 2014). Another study demonstrated that the overall endothelium-dependent relaxation to ACh was not altered quantitatively, but there were alterations in the mechanisms mediating relaxation in chronically stressed WKY and BHR rats (Fuchs et al. 1998). It was found that exposure to 10 days of behavioral stress enhanced the role of vasodilator COX products in small mesenteric arteries of WKY rats (Fuchs et al. 1998). However, the inhibition of NOS activity had a significantly larger inhibitory effect on ACh-induced relaxation (suggesting an enhanced role of NO) in small mesenteric arteries from stressed BHR rats (Fuchs et al. 1998). In our studies 8-week chronic social stress reduced NOS activity in the aorta of adult male BHR and SHR (Bernatova et al. 2007a) in contrast to normotensive rats. In contrast, 2-week crowding stress significantly elevated NO production in the aorta of pubertal female BHR and SHR (Slezak et al. 2014) while only a non-significant increase was observed in age-matched males (Bernatova et al. 2015). Similarly, in pubertal BHR males there were no differences in endothelium-dependent vasorelaxation of the femoral artery, including its NO-dependent and NO-independent components, between the stressed and control groups (Bernatova et al. 2015).

These studies demonstrated that long-term psychosocial stress (both crowding and mild unpredictable stress model) can reduce endothelium- dependent relaxation due to suppressed NO-independent component of relaxation in various arteries, while the NO-dependent component of relaxation may remain elevated. Thus, NO-independent endothelial dysfunction might be the initial step in the development of stressinduced CVDs, including vascular remodeling followed by atherosclerosis and/or hypertension in normotensive subjects. In contrast, according to our studies, vascular L-arginine/NO system supposedly protects adult male normotensive rats from the development of stressinduced hypertension. However, the ability of NOS to produce NO may be variable in the course of stress and this protective system may be subsequently insufficient to balance vasoconstriction and BP elevation in stress. Moreira et al. (2016) suggested that behavioral stressinduced increases in NO production may trigger a massive impact on vascular cells and to accelerate cardiovascular complications under oxidative stress conditions as it was described in diabetes mellitus.

Yet, it is noteworthy that the effect of stress on vascular endothelial function may differ at various arterial sites because of different local hemodynamic milieu and arterial receptor number and function.

\section{How can stress influence the endothelium- dependent NO-mediated vascular function?}

Despite many discrepancies, several possible mechanisms for endothelial damage following stress have been described. The stressor-induced activation of the SNS and HPA axis, resulting in the secretion of catecholamines and glucocorticoids, can alter endothelial and vascular smooth muscle cell function by triggering the secretion of endothelial endothelin-1, cytokines and the production of ROS (Ullian 1999, Nickel et al. 2009, Goodwin and Geller 2012). It was shown that hemodynamic factors, for example elevations in HR and associated blood flow disturbances, can contribute to early endothelial damage in stress (Strawn et al. 1991, Skantze et al. 1998). Skantze et al. (1998) pointed out that psychosocial stress (socially unstable condition for $72 \mathrm{~h}$ ) induces endothelial injury in adult male cynomolgus monkeys, and this effect was mediated via $\beta_{1}$-adrenoceptor activation. In humans, sympathetic stimulation, at a clinically relevant range, significantly impaired endothelium-dependent flow-mediated dilation by an $\alpha$-adrenergic mechanism (Hijmering et al. 2002). Pettersson et al. (1990) demonstrated the relation between adrenergic activation, HR and endothelial injury 
both in unbranched and in circumostial areas of arteries.

It is well known that blood vessels in vivo are constantly under the influence of hemodynamic forces, including shear stress, hydrostatic pressure and cyclic strain. Hemodynamic forces, which are altered during increased sympathetic arousal, are important determinants of vascular homeostasis and may be involved in stress-related vascular reactivity changes. Shear stress, which is the tangential frictional force acting on the vascular endothelial cells due to blood flow, has been shown to mediate blood flow-induced vasodilatation (Smiesko et al. 1985, Cábel et al. 1994). Graded increase in shear stress promotes eNOS expression and activity, leading to enhanced NO formation (Hsieh et al. 2014, Sriram et al. 2016). High blood flow-induced shear stress is also an important factor in the NO-dependent regulation of peripheral vascular resistance (Smieško and Johnson 1993). Irregular or disturbed flow pattern and shear stress result in higher levels of ROS which reduce NO bioavailability (Hsieh et al. 2014). In this regard, oxidative stress is an important determinant in the development of endothelial dysfunction (Payne et al. 2003, Daiber et al. 2016). Additionally, ROS alter prostaglandin metabolism, endothelin-1 signaling and $\mathrm{H}_{2} \mathrm{~S}$-mediated mechanisms (Bernatova 2014) and promotes novel oxidative posttranslational protein modifications that interfere with endothelial signaling. In addition to the reduction of bioavailable NO, ROS may also reduce endothelium-dependent hyperpolarization and $\mathrm{PGI}_{2}$ synthesis (Bachschmid et al. 2013), promoting the arterial contraction. Moreover, increased concentration of ROS or oxidative stress markers were documented in acute and chronic stress in both human and animal studies (Sivonová et al. 2004, Zafir and Banu 2007, Kwiecien et al. 2008, Zafir and Banu 2009, Takaki 2013, Moreira et al. 2015, Moreira et al. 2016, Said and El-Gohary 2016).

In our study, the application of 2-week crowding in young female rats elevated aortic ROS only in WKY rats, while a decrease of aortic ROS was observed in SHR (Slezak et al. 2014). This surprising finding may result from a better capacity of the antioxidant defense system in young (pre)hypertensive rats, which may be damaged in later periods of life (Horvathova et al. 2016). On the other hand, ROS possess an important role in signal transduction. Very recently we have shown that the lack of ROS resulted in greater stress-induced MAP decrease and prolongation of time required to reach new poststress steady state of BP in acutely air-jet stressed rats with inhibited SNS function and NO production, showing an important role of ROS in BP regulation during acute stress (Bernatova et al. 2016). Furthermore, the involvement of HPA axis in the alterations of endothelial NO activity is described below.

\section{Interactions of NO with SNS in stress}

It is well known that sympathetic activation plays a significant role in BP regulation in both normal and pathological conditions. It has also an important role in the development of stress-induced hypertension. In humans, elevated sympathetic nerve activity contributes to the pathogenesis of essential hypertension (Penesova et al. 2008, Garafova et al. 2014, Grassi and Ram 2016) and the interventions targeting sympathetic activation have been considered as an important strategy for attenuating hypertension (Mancia et al. 2013). Moreover, essential hypertensive patients have greater sympathetic reactivity in response to acute stress (Kaushik et al. 2004, Kellerová 2013, Garafova et al. 2014). Several studies suggested reciprocal inhibitory effects between SNS activity and $\mathrm{NO}$, both in the vasculature and central nervous system (CNS). Hence, the mechanisms involved in the development of stress-induced hypertension may include the dysregulation of SNS and coupled NO pathways (Esch et al. 2002a).

Central NO is hypothesized to participate in the regulation of autonomic function by decreasing sympathetic output to the periphery. Deficient neuronal NO production is thought to cause sympathetic overactivity that can contribute to NO-deficient hypertension (Sander and Victor 1999). In Wistar rats, inhibition of NOS in posterior hypothalamic area, which is involved in central cardiovascular regulation, induced BP increase (Gerová et al. 1995). Similarly, Shapoval et al. (1991) demonstrated an increase in BP after NOS inhibition in the vasomotor centers of the ventrolateral medulla. Sander et al. (1995) prevented BP increase after NOS inhibition by pharmacological peripheral sympathectomy. However, more recent experimental studies showed that NO signaling in the brain may be both pro- and anti-hypertensive, depending on the area of the brain and NOS isoform. Inhibitory effect of e/nNOSproduced NO on SNS activity was observed in hypothalamic paraventricular nucleus (PVN) (Zhou et al. 2014) and eNOS-produced NO in the nucleus tractus solitarii (NTS) (Cheng et al. 2013, Wu et al. 2016). Chronic interference of nNOS dimerization required for generation of NO within the PVN potentiated the increase 
of BP by modulating the sympathoexcitation that accompanies renovascular hypertension (Rossi et al. 2010). NO has also been shown to inhibit renal sympathetic outflow by modulating local GABAergic activity within the PVN (Zhang and Patel 1998). In propofol-anesthetized rats, nNOS-derived $\mathrm{NO}$ at the rostral ventrolateral medulla (RVLM) induced sympathoexcitation via both N-methyl-D-aspartate (NMDA) and non-NMDA receptors while NO generated by iNOS elicited sympathoinhibition via $\mathrm{GABA}_{\mathrm{A}}$ receptors (Chan et al. 2003). In contrast, chronic overexpression of iNOS in the RVLM of normotensive rats increased BP via SNS activation and oxidative stress (Kimura et al. 2005). Moreover, iNOS levels in the RVLM were significantly higher in SHR than in WKY rats and microinjection of aminoguanidine (iNOS inhibitor) into the RVLM dose-dependently decreased BP and HR in SHR, but not in WKY rats. These findings suggest that iNOS expression in the RVLM of SHR contributes to BP increase (Kimura et al. 2009). On the other hand, overexpression of eNOS in rat RVLM decreased BP, HR and urinary excretion of NA, indicating that eNOS lowers the central sympathetic outflow (Kishi et al. 2001).

Accumulating evidence for a modulation of sympathetic neurotransmission by endogenously produced NO shows that NO restricts the release of sympathetic transmitters at the level of adrenal medulla (Torres et al. 1994, Zanchi et al. 1995, Kvetnansky et al. 1997) and at nerve terminals of the heart and vessels (Addicks et al. 1994, Schwarz et al. 1995, Kyselá and Török 1997). L-NAME-treated rats had markedly increased plasma levels of adrenaline, NA and dopamine metabolites at rest and during immobilization stress (Kvetnansky et al. 1997). A significant increase of NOS activity in the adrenal medulla was observed in the acutely immobilized animals (Kishimoto et al. 1996). Thus NO may efficiently suppress the stress discharge of catecholamines from the adrenal glands. In addition, NO from adrenomedullary chromaffin cells could be implicated in the autoinhibitory process of catecholamine release (Torres et al. 1994). These findings demonstrated that adrenaline, dopamine and NA release at the periphery is under the inhibitory control of endogenous NO. On the contrary, Orlando et al. (2008) found that the absence of nNOS-derived NO in nNOS knock-out mice reduced the capacity of adrenaline-synthesizing enzymes in the adrenal glands to respond to acute stressor exposure with an adequate adrenaline release.
In the vasculature, NA is the main neuromediator of SNS. In healthy animals the vasodilating EDRFs are produced in large amounts enabling the endothelium to oppose the vasoconstricting tone generated by the activity of the SNS. NO inhibits NA-dependent vascular contraction and by this mechanism it is capable to lower arterial BP. Thus under normal conditions the endothelial NO negatively modulates the activity of the adrenergic portion of sympathetic neurotransmission (Török 2008). Endothelial damage impairs the balance between vasoconstriction and vasodilatation (Holécyová et al. 1993). The studies, in which NO production was reduced by acute non-specific inhibition of NOS showed immediate BP increase, indicating that NO counteracts the vasopressor effects of SNS (Zicha et al. 2014). Indeed, L-NAME-induced hypertensive response was significantly attenuated with chronic $\alpha$ - and $\beta$-adrenergic receptor blockade in diabetic rats (Fitzgerald and Brands 2002). Similarly, Dobesova et al. (2002) confirmed the major importance of both sympathetic hyperactivity and relative NO deficiency for the maintenance of salt hypertension in Dahl rats. Interestingly, using a sequential blockade of reninangiotensin system (RAS), SNS and NOS Kuneš et al. (2004) revealed a characteristic imbalance between sympathetic activity and relative NO deficiency in most of the examined models of experimental hypertension. In addition to these facts, the important role of NO in limiting the peripheral action of catecholamines is supported by the findings that inhibition of NO synthesis results in hypertension, as mentioned above.

Increased BP in SHR is usually caused by high activity of SNS. Yet in SHR, in which elevated SNS activity (Okamoto et al. 1967, Lee et al. 1991, Korner et al. 1993, Paulis et al. 2007, Pintérová et al. 2010, Zicha et al. 2014) and increased NA release from the hypothalamus (Qualy and Westfall 1988, Pacák et al. 1993) were observed, contradictory findings were published with regard to NO production in the various brain areas. Reduced nNOS activity and protein expression were found in the brainstem but not in the diencephalon of adult SHR (Hojná et al. 2010). In contrast, elevated eNOS expression was observed in the brainstem of SHR in another study of this research group (Hojná et al. 2007). No changes in nNOS gene expressions were found in 4-week-old (pre-hypertensive) SHR in the hypothalamus, dorsal pons, dorsal medulla, RVLM and caudal ventrolateral medulla while elevated nNOS were determined in the hypothalamus, dorsal 
medulla and caudal ventrolateral medulla of 14-week-old SHR vs. age-matched WKY or SD rats (PlochockaZulinska and Krukoff 1997). These data show that gene expression of nNOS is increased in central autonomic centers in animals with increased sympathetic activity and they support the hypothesis that NO plays an important role in the maintenance of homeostatic balance through the attenuation of sympathetic activity (Plochocka-Zulinska and Krukoff 1997). We have observed unchanged NOS activity in the hypothalamus of adult male SHR despite elevated BP and HR (Bernátová 2006, Bernatova et al. 2007a). Discrepancies seem to result from differences in the age, methods used for determination of NO production (i.e. individual NOS gene expression, protein expression or NOS activity) and studied areas of the brain. On the other hand, the failure to correct spontaneous hypertension by NO donors administration (Kristek et al. 2003) reflects the fact that sympathetic overactivity plays a key role in this form of hypertension, while NO production in SHR might be enhanced to compensate increased BP (Török 2008, Púzserová et al. 2013a, Zicha et al. 2014).

Regarding stress conditions, it was found that NO production is considerably modified in the SNS and HPA system during stress and is related to the duration of stress (acute vs. chronic) as well as the time-course of chronic stress. Accentuated expression of nNOS mRNA was observed in the PVN of acutely restrained rats (de Oliveira et al. 2000) and elevated nitrate/nitrite levels were observed in PVN dialysate of shaker-stress exposed rats (Kawa et al. 2002). The elevation of NOS activity and nNOS mRNA expression was observed in the PVN of rats exposed to short-term immobilization (Kishimoto et al. 1996). Furthermore, the rise in angiotensin II type 1 $\left(\mathrm{AT}_{1}\right)$ receptor mRNA levels in the hypothalamus and hippocampus after stress or repeated treatment with L-NAME as well as the correlation between $\mathrm{AT}_{1}$ receptor mRNA and NOS mRNA in the brain suggest an interaction between the central angiotensin II and NO (Kiss et al. 2001, Krizanova et al. 2001). The importance of NO formation in the brain to counteract stimulatory effects of central angiotensin II on the sympathetic tone was also suggested (Dampney et al. 2005).

Interesting data were provided by Leza et al. (1998) who found the elevation of brain NOS activity and cyclic guanosine monophosphate (cGMP) content in lean rats after 4 and 9 days of stress while normal levels were seen after 14 days. These authors also suggested that the role of NO during chronic stress in the brain appears to be detrimental as this molecule mediates glutamatedependent hippocampal damage during chronic stress. In contrast, increased generation of NO in the vascular system may attenuate the vasoconstrictor and platelet aggregatory effects of catecholamines and other mediators of stress (Leza et al. 1998).

In our studies, 8-week crowding had no effect on hypothalamic NOS activity in adult Wistar, Wistarmothered BHR, SHR-mothered BHR and SHR rats (Bernatova 2006, Bernatova et al. 2007a). It is of interest that in young male rats, both WKY and SHR-mothered BHR, 2-week crowding reduced NOS activity in the brainstem, cerebellum and hypothalamus and these changes persisted two weeks after cessation of crowding, while in a tendency of increased NOS activity was seen in the aorta of stressed rats (Bernátová et al. 2015). In line with our studies, total NOS activity in the hypothalamus and nNOS-immunoreactive cell density in the PVN were both significantly decreased while plasma $\mathrm{NO}$ and corticosterone (pCort) levels were elevated in the rats exposed to chronic unpredictable stress (Gao et al. 2014). This finding suggests that NO production in the circulation and in the brain may be differently affected by chronic stress.

Regarding the periphery, a number of studies have assessed stress-induced changes in adrenergic vasoconstriction, but the findings are variable. Parra $e t$ al. (1994) evaluated the effect of either 7-14 or 30-35 days of social deprivation stress in Wistar rats on constriction of the aorta. Interestingly, constriction of the aorta to NA was impaired after 7-14 days of stress while 30-35 days of stress resulted in elevation of aortic constriction, suggesting the differences in the course of stress. Acute and chronic stress in normotensive Wistar rats caused a decrease in the reactivity of blood vessels to adrenergic stimuli (Cordellini and Vassilieff 1998, Cordellini et al. 2006). In these studies, the enhanced role of NO was suggested, because L-NAME administration and endothelium removal abolished the stress-induced aortic hyporeactivity (Cordellini et al. 2006) and the SAS participated in hyperactivity of the endothelial NO system induced by stress (Navarro-Oliveira et al. 2000). In addition, we observed a different effect of 8-week crowding on adrenergic constriction of the femoral artery in normotensive Wistar and WKY rats. While crowding resulted in elevated NA-induced vasoconstriction in Wistar rats (Bernatova et al. 2007a), WKY rats showed slightly impaired adrenergic vasoconstriction (Puzserova et al. 2006). Reduced NA-induced vasoconstriction in 
crowded WKY rats may result either from functional down-regulation of $\alpha$-adrenoceptors or from the elevated basal NO synthesis (Puzserova et al. 2006). Interestingly, in young female rats the exposure to 2-week crowding stress significantly impaired contraction to NA only in BHR but not in WKY and SHR (Slezak et al. 2014). Similar results were obtained by Fuchs et al. (1998), when the exposure to 10 days of behavioral stress decreased phenylephrine-induced ( $\alpha$-adrenoceptormediated) contraction in BHR rats, but not in WKY rats. On the other hand, 5 weeks of unpredictable stress increased the in vitro $\alpha$-adrenoceptor-mediated constrictor response of the aorta in SD rats which was related to deficiency in NO production (Neves et al. 2009). Similarly, chronic stress increased neurogenic contractions of the superior mesenteric artery elicited by electrical stimulation of perivascular sympathetic nerve endings and significantly elevated vasoconstriction induced by exogenous NA, without modulation of BP and HR (Puzserova et al. 2012).

Altogether, abovementioned studies suggest that the duration of the stress stimulus, strain, sex and age considerably modify the NO-SNS interaction in stressful conditions.

\section{NO and HPA axis interaction in stress}

Regulation of the stress systems is extremely complex and occurs at multiple levels. After the exposure to stressor, sympathetic activation is followed by activation of HPA axis and elevated secretion of $\mathrm{CRH}$ (from the hypothalamus), ACTH (from the anterior pituitary) and glucocorticoids (from the adrenal cortex, in humans mainly cortisol, in rats mainly corticosterone).

Under acute stressful conditions, the negative feedback mechanism maintains the homeostasis of HPA axis. On the other hand, chronic stress-induced hyperactivity of HPA axis results in persistently elevated glucocorticoids (GC) levels (Zhu et al. 2014). The elevated GC reach various regions of the brain including hippocampus, hypothalamus, pituitary, etc. (Zhu et al. 2014). Glucocorticoids have a significant role in the metabolic response, mobilization of energetic sources and brain function (McEwen 2007). In addition, GC may affect both central mechanisms of $\mathrm{BP}$ regulation and vascular function. Hypertension is a prominent feature in patients with Cushing's syndrome characterized by an excess of systemic GC (Peppa et al. 2011). It is also well known that hypertension is the major cardiovascular side effect of systemically administered GC (Walker and Edwards 1994). However, a variety of mechanisms have been proposed to explain exogenous and endogenous GC-induced hypertension (Peppa et al. 2011, Goodwin and Geller 2012).

NO is also a critical neurotransmitter and biological mediator of the neuroendocrine axis. NO-dependent control of central links of the stress reaction is supported by the fact that the pituitary gland receives a rich NO-ergic innervation (NOS-containing neurons) from the hypothalamus, including the paraventricular and supraoptic nuclei, suggesting regulatory role of NO not only in HPA axis but also in the posterior lobe of the pituitary (Vanhatalo and Soinila 1995).

$\mathrm{NO}$ is an important factor controlling $\mathrm{CRH}$ and ACTH release (Karanth et al. 1993, Lee et al. 1999, Rivier 2001). It is involved in central stimulation of the HPA axis by $\alpha_{1}$ - and $\alpha_{2}$-adrenergic receptor agonists, and in mediation of the stimulatory action of these agonists on ACTH and GC secretion (Bugajski et al. 1999b). A significant increase of NOS activity and nNOS mRNA expression in the anterior pituitary was observed in rats exposed to acute immobilization as compared to nonstressed control rats (Kishimoto et al. 1996). Moreover, Karanth et al. (1993) showed that interleukin-2 activates $\mathrm{CRH}$ release from the hypothalamus by increasing NO production in which constitutive NOS is involved. Blockade of NO formation with L-NAME significantly blunted the ACTH response to stressors, suggesting that endogenous NO may exert a stimulatory effect on the circuitries leading to increased plasma ACTH levels during stress (Rivier 1994). On the other hand, the agonists of muscarinic and nicotinic acetylcholine receptors, carbachol and nicotine, increased plasma levels of ACTH and corticosterone in rats, and this effect was potentiated by NOS inhibitors (Gadek-Michalska and Bugajski 2005, Bugajski et al. 2006). Bugajski et al. (2006) found that NO significantly impairs the carbacholinduced HPA axis activation in rats under basal and social stress conditions. The same research group also demonstrated that NO acts as an inhibitory modulator of ACTH and corticosterone secretion in vasopressininduced HPA axis activation in control and stressed rats (Bugajski et al. 1999a).

Moreover, NO is also important in the control of GC release. Tsuchiya et al. (1997) demonstrated that acute immobilization-induced increase of NO synthesis in the adrenal cortex can modify the stress-induced 
corticosterone response to facilitate the recovery from the elevated corticosterone secretion by stress in the adrenal cortex to the resting basal level. In addition, an increase of NOS activity and up-regulation of nNOS mRNA expression in adrenal cortex was detected by Kishimoto et al. (1996) after a short immobilization stress. Similarly, in male Wistar rats the acute restraint stress markedly elevated pCort levels which were attenuated by pretreatment with L-arginine, a substrate for $\mathrm{NO}$ synthesis, but not by NOS inhibitor (L-NAME or 7-NI) pretreatment (Gulati et al. 2006). Moreover, stress gastric ulcers were attenuated by L-arginine and aggravated by L-NAME (Gulati et al. 2006). In the adrenal glands, elevated NO production was observed after acute immobilization, unaltered values after 4 and 9 days of stress and reduction of NO production was present after 14 days of stress exposure (Leza et al. 1998). In our studies, 8-week crowding had no effect on pituitary NOS activity in adult male Wistar and Wistar-mothered BHR rats, however elevated NOS activity was determined in the adrenal glands (Bernatova 2006, Bernatova et al. 2007a). In addition, different effects of stress on NO production were observed in other rats with a positive family history of hypertension (Bernatova 2006). Unchanged NOS activity was found in the pituitary and adrenal glands in male SHR-mothered BHR after 8-week crowding. However, in SHR, reduced NOS activity in the pituitary and unchanged NOS activity in the adrenal glands were found after the exposure to the same stressor (Bernatova 2006). Thus, it seems that alterations in NO production in the individual parts of the SNS and HPA axis during stress depend on the duration of stressor as well as on the genetic predispositions of experimental subjects.

Long-term stress may result in partial attenuation of stress-induced GC release as compared with acute or short-term stimuli. Habituation to stress is a normal response, since without physiological compensation there could be escalating detrimental effects on the organism. Indeed, for repeated restraint stress (Chen and Herbert 1995, Bauer et al. 2001), social stress (Chung et al. 1999), noise stress (Armario et al. 1986) and forced swimming (Cox et al. 1985) there is a habituation of GC responses. Similarly, an attenuation of corticosterone response was observed in mice exposed to chronic shaker stress, although there was still a more than 4-fold increase in pCort compared to controls (Bernatova et al. 2002a). However, in contrast to mice, a study in rats showed no attenuation of the pCort response to repeated shaker stress (Hashiguchi et al. 1997).

It also seems that NO is a crucial mediator in HPA axis regulation under chronic stress. Although acute GC elevation in the hippocampus and hypothalamus exerted a negative regulation of HPA axis, chronic GC elevation in the hippocampus, but not in the hypothalamus, accounted for chronic stress-induced hyperactivity of HPA axis due to impairment of its negative feedback regulation. GC activate the mineralocorticoid receptor (MR)-nNOS-NO pathway which results in the disruption of glucocorticoid receptors (GR) expression in the hippocampus, finally inducing HPA axis hyperactivity (Zhu et al. 2014). Therefore, NO produced by nNOS in the hippocampus is crucial in chronic stress and GC-induced hyperactivity of HPA axis (Zhou et al. 2011, Zhu et al. 2014). Thus, NO is an important regulator of HPA axis, which seems to be involved in both its activation and attenuation.

In our studies, 2-week crowding elevated pCort and systolic BP in SHR-mothered BHR of both sexes and male SHR while only mild pCort effect was observed in WKY and female SHR (Slezak et al. 2014, Bernatova et al. 2015). Interestingly, in our study pCort remained elevated, whereas NOS activity in the hypothalamus, cerebellum and brainstem remained decreased two weeks after cessation of chronic crowding stress in young BHR males (Bernatova et al. 2015). Persisting increase of pCort after cessation of stress may result from epigenetic mechanisms such as DNA methylation of GR (Turecki and Meaney 2016) which may deteriorate negative feedback regulation of HPA axis.

In experimental studies, Bechtold et al. (2009) found that endogenous corticosterone may act also via hindbrain GR to enhance the pressor response to stress in adult male BHR, but it promotes the adaptation in WKY rats. Subsequently, long-term GC overload may reduce expression and activity of individual NOS isoforms in various brain areas as well as in the cardiovascular system. Furthermore, it has been shown that GC led to alterations in neuronal NO release in the CNS, which is an important mechanism in hypertension development (Goodwin and Geller 2012).

In the vasculature, $\mathrm{GC}$ receptors are present on the endothelium and vascular smooth muscle cells (Provencher et al. 1995, Ray et al. 1997, Rogers et al. 2002). Glucocorticoids can act as modulators of both vascular smooth muscle and endothelial functions (Goodwin and Geller 2012). GC were shown to support 
vasoconstriction as they increase the response to NA, angiotensin II and other vasoconstrictors (Grunfeld et al. 1985, Walker and Edwards 1994, Saruta 1996, Ullian 1999, Peppa et al. 2011). Saruta (1996) found that the number of $\mathrm{AT}_{1}$ receptors of vascular smooth muscle cells is significantly increased by GC. Moreover, increased synthesis and secretion of endothelin-1 (the strongest vasoconstrictor), increased vascular smooth muscle cytosolic calcium levels, increased synthesis of catecholamines and $\beta_{1}$-adrenergic receptor expression, increased availability of $\alpha_{1}$-adrenergic receptors on vascular smooth muscles, enhanced synthesis and action of neuropeptide $\mathrm{Y}$ and vasopressin and the activation of RAS were found to be pathogenetically involved in the corticosteroid-induced hypertension (Peppa et al. 2011). In addition, Falardeau and Martineau (1989) found that GC-induced hypertension is associated with an inhibition of prostacyclin biosynthesis and an alteration of its metabolism. Furthermore, Molnar et al. (2008) suggested that GC may contribute to vascular disease also via MR signaling.

Glucocorticoids were also shown to participate in the regulation of vascular NO production. The inhibitory effect of GC on eNOS expression and NOx production was observed in cultured bovine coronary artery and aortic endothelial cells as well as in human umbilical vein endothelial cells (Wallerath et al. 1999, Rogers et al. 2002). Incubation of cultured human umbilical vein endothelial cells or bovine aortic endothelial cells with dexamethasone (synthetic glucocorticoid) reduced eNOS mRNA and protein expression, an effect that was prevented by the GR antagonist mifepristone (Wallerath et al. 1999). Moreover, BP increase, plasma NOx (an indicator of total body NO synthesis) decrease together with the downregulated expression of eNOS were found in the aorta and several other tissues of GC-treated rats (Wallerath et al. 1999). Rogers et al. (2002) demonstrated that cortisol, via activation of GR, suppresses NOx release in cultured bovine coronary artery endothelial cells by downregulation of eNOS proteins and inhibition of intracellular $\mathrm{Ca}^{2+}$ mobilization. Furthermore, Simmons et al. (1996) found that GC inhibited NO production by iNOS in cardiac microvascular endothelial cells following cytokine exposure and this was mediated by limiting a NOS cofactor tetrahydrobiopterin $\left(\mathrm{BH}_{4}\right)$ and NOS substrate L-arginine availability. Mitchell et al. (2004) showed that dexamethasone via GR-mediated decrease of guanosine triphosphate cyclohydrolase I
(GTPCH1 - the rate-limiting enzyme for the de novo synthesis of $\mathrm{BH}_{4}$ ) mRNA expression and GTPCH1 downregulation contributes to $\mathrm{GC}$-induced reduction of endothelium-dependent relaxation in the isolated rat aorta. Moreover, GC responsive elements in the eNOS gene promoter region were demonstrated by Liu et al. (2009). These studies suggested that the primary mechanism of GC-induced hypertension may result rather from the $\mathrm{GC}$ action on the vascular tissues than from excessive sodium and water reabsorption after the activation of renal MR-associated mechanism (Goodwin et al. 2011, Goodwin and Geller 2012).

In vivo studies demonstrated that dexamethasone increased MAP in wild-type C57 B16 mice (eNOS ${ }^{+/+}$ mice), but had no effect on BP in $\mathrm{NOOS}^{-/-}$mice derived from the same strain (Wallerath et al. 2004). The authors concluded that the expressional down-regulation of eNOS and the ensuing reduction of vascular NO production contributes to hypertension caused by GC. Goodwin et al. (2011) found that knock-out of the vascular endothelial GR abrogates dexamethasone-induced hypertension. Moreover, dexamethasone reduced neuronal NO release from the perivascular innervation of the mesenteric arteries in SHR but not WKY rats (Aras-Lopez et al. 2009), which also proves an important role of GC in development of stress-induced hypertension in predisposed subjects. GC were also shown to increase oxidative stress (Duckles and Miller 2010), which seems to play an important role in the development of endothelial dysfunction as mentioned above. Thus GC may alter NO release from the endothelium, CNS and perivascular nervous system. In addition, corticosteroidinduced metabolic abnormalities, such as hyperglycemia, excess liberation of free fatty acids, increased plasma levels of triglycerides, insulin resistance and hyperinsulinemia exert pathological impact on endothelial function and appear to contribute to the corticosteroid-induced hypertension (Peppa et al. 2011, Zhang et al. 2012).

Above mentioned findings support the theory that GC affect the vascular smooth muscle cells and endothelium, induce the imbalance between vasoconstriction and vasorelaxation, favoring vasoconstriction, and resulting in the increase of systemic vascular resistance and BP increase.

\section{Oxytocin and vasopressin}

Hormones of the posterior pituitary, oxytocin 
(OT) and vasopressin (VP), represent an important component of the stress response (Jezova et al. 1995, Ondrejcakova et al. 2010, Danevova et al. 2013, Babic et al. 2015). OT and VP are involved in the regulation of BP and other cardiovascular functions (Gutkowska et al. 2000). There are studies showing that OT and VP are involved in the pressor and HR responses to stressors (Callahan et al. 1992, Morris et al. 1995, Bernatova et al. 2004, Ondrejcakova et al. 2010). There was a sustained reduction of $\mathrm{BP}$ in OT knock-out (OTKO) mice at rest, while accentuated BP responses were observed in chronic stress (Bernatova et al. 2004). Wsół and colleagues reported that central application of an OT receptor antagonist enhanced BP and HR increases elicited by environmental stress (Wsół et al. 2008, Wsół et al. 2009). In addition, simulated stress-induced oxytocin secretion by chronic treatment with oxytocin via osmotic minipumps led to reduced pressor response to $\alpha_{1}$-adrenergic receptor agonist (Ondrejcakova et al. 2010). These studies provide the evidence that OT may play a role in the attenuation of stress-induced pressor response.

Concerning the interaction of NO and neurohypophysial hormones, several studies emphasized the inhibitory action of centrally produced $\mathrm{NO}$ on the secretion of OT and VP hormones (Stern and Ludwig 2001, Reis et al. 2007) (Fig. 2). However, Wangensteen et al. (2003) reported that the administration of nNOS inhibitor 7-NI to normal rats produced a mild polyuriapolydipsia syndrome, which has been attributed to an inhibitory effect of 7-NI on VP release. Moreover, in chronic L-NAME-treated rats, plasma VP levels have been reported to be unchanged (Liu et al. 1998). Rettori et al. (1997) showed that OT stimulates NOS in the hypothalamus via NA, resulting in an increased NO release. Furthermore, the released NO can act back on oxytocinergic terminals to suppress the release of OT in an ultrashort-loop negative feedback. With regard to the HPA axis, there was a reduction of stress-induced corticosterone release in chronically stressed OTKO mice (Bernatova et al. 2004). This fits with findings of Gibbs (1985) who observed a reduction in stress-induced ACTH levels when OT was neutralized with specific antisera. Data suggest that OT accentuates ACTH-dependent GC release. On the other hand, VP has only a weak ability to upregulate the ACTH secretion, but it markedly potentiates the effects of CRH (Oshikawa et al. 2004), suggesting its role in upstream regulation of HPA axis. Both hormones, OT and VP, were shown to interact to each other and with the HPA axis and thus supposedly contribute to BP regulation under stress conditions.

In addition, OT synthesis and OT receptors (OTR) were also proved in the heart and large vessels (Gutkowska et al. 2000). Miller et al. (2002) have demonstrated the presence of OTR in the small resistance arteries. Therefore, OT (including locally produced peptide) may have important regulatory functions in the heart and vasculature, including negative chronotropic effect on the heart and the regulation of local vascular tone via stimulation of NO-cGMP pathway (Thibonnier et al. 1999, Gutkowska et al. 2000). Experiments with primary cultures of human endothelial cells revealed that these cells express OTR and their stimulation by OT produced mobilization of intracellular $\mathrm{Ca}^{2+}$ and the release of NO (Thibonnier et al. 1999).

However, the studies investigating effect of OT on vascular function produced ambiguous results. High concentrations of OT induced renal vasoconstriction in the rats by activating vasopressin $\mathrm{V}_{1 \mathrm{~A}}$ receptors (Loichot et al. 2001). Both OT and VP caused endotheliumdependent relaxation in the isolated canine basilar artery by activating $\mathrm{V}_{1}$ receptors, in contrast to the femoral artery, in which these hormones caused endotheliumindependent contractions (Katusic et al. 1986). Using a wire myograph system, Miller et al. (2002), showed that OT failed to produce vasorelaxation in the preconstricted small mesenteric arteries, uterine arcuate arteries and thoracic aorta from nonpregnant and pregnant rats, and high concentrations of OT caused $\mathrm{V}_{1 \mathrm{~A}}$-receptormediated vasoconstriction. These findings reflect the marked variation of responses to OT and VP in different vascular beds. Thus, despite the fact that vascular endothelial cells express OTR, the involvement of OT/OTR/NO system in modulation of vascular resistance and BP in stress is still unclear.

Thus, the exact OT and VP action in BP regulation and their relationships with $\mathrm{NO}$ in the brain and cardiovascular system during stress needs further examination.

\section{NO involvement in BP regulation during stress}

$\mathrm{NO}$ is recognized as an important signaling molecule in the CNS and periphery, and this includes a significant influence on the activity of stress systems (Fig. 2). After the exposure to stressor the SNS activation is followed by the activation of its sympathoadreno- 
medullary part and RAS, which is followed by elevation of ROS, alterations in endothelial function and decrease of endothelial NO (eNO) bioavailability, which collectively results in the elevation of BP. Regarding the SNS activity, there is no consensus on the opposing actions of NO produced in different brain regions on SNS activity. Several studies suggested that NO reduces sympathetic output to the peripheral tissues. In chronic stress the effect of neuronal NO (nNO) on the SNS activity (mainly on the central sympathetic outflow) remain unresolved. However, an increase in the sympathetic influences to the peripheral vessels (resulting in reduced eNO bioavailability), participates in the development and progression of the hypertensive state.

Meanwhile, the activation of HPA axis, in which $\mathrm{nNO}$ seems to be important, leads to increased release of
GC. In acute (or short-term) stress, GC increase mediates the attenuation of HPA activity. In the hypothalamus, NO contributes to the negative control of HPA axis activity (Mancuso et al. 2010). In the hippocampus nNOS-derived NO is an important molecule in the development of HPA axis hyperactivity during chronic stress (Zhu et al. 2014). Thus NO exerts both stimulatory and inhibitory effect within the HPA-axis depending on the brain area. In addition, NO produced in the adrenal cortex may inhibit GC release in stressed conditions. Our results showed that in chronic stress reduced NO in the selected brain areas was associated with high activity of HPA axis and elevated BP in prehypertensive rats. It is also evident that chronically elevated GC can cause hypertension by acting on the endothelium, in which reduces eNO bioavailability.

\section{STRESSOR}

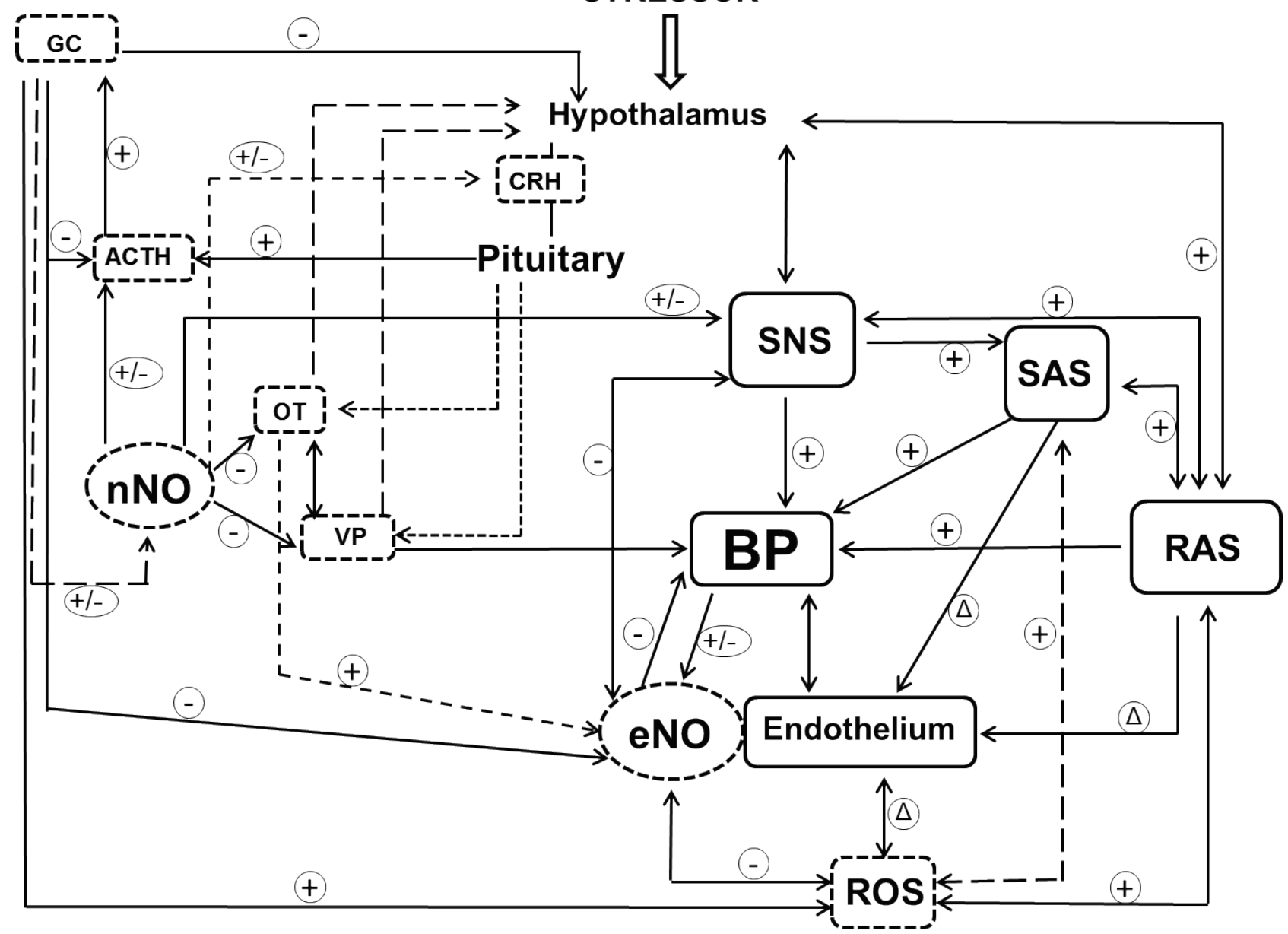

Fig. 2. A simplified scheme of nitric oxide involvement in the main blood pressure regulatory mechanisms in stress. Inhibiting effects are marked by "minus" mark, activating effects are marked by "plus" mark. The alterations in endothelial function (including those other than NO-mediated) are marked by $\Delta$. ACTH - adrenocorticotropic hormone, BP - blood pressure, CRH - corticotropin releasing hormone, eNO - nitric oxide synthesized by endothelial nitric oxide synthase, GC - glucocorticoids, nNO - nitric oxide synthesized by neuronal nitric oxide synthase, NO - nitric oxide, OT - oxytocin, RAS - renin-angiotensin system, ROS - reactive oxygen species, SAS - sympathoadrenomedullary system, SNS - sympathetic nervous system, VP - vasopressin. 
OT and VP were shown to interact to each other and with the HPA axis and supposedly to contribute to $\mathrm{BP}$ regulation under stress conditions. Concerning the interaction of NO and neurohypophysial hormones, several studies emphasize the inhibitory action of centrally produced NO on the secretion of OT and VP hormones. However, the exact BP regulation associated with the OT and VP action and their relationships with NO in the brain and CVS during stress remain largely unexplored.

Of course, Figure 2 is not exhausting scheme of $\mathrm{BP}$ regulation in stress. Other regulatory mechanisms, the involvement of which is variable in the course of stress, are also involved, and not all of them are satisfactorily elucidated by now. Together, these mechanisms create a very complex network of mutual regulations and feedbacks, in which failure of one mechanism can be compensated by the other one. Yet long-term SNS activation and dysregulation of HPA axis during chronic and repeated exposure to stressors may destroy this precise network leading to hypertension development. Although the role of endogenous NO in regulation of the activity of HPA axis and SNS remains controversial, a large body of evidence demonstrates that $\mathrm{BP}$ regulation in stress closely depends on the interactions among NO and stress systems.

\section{Conclusions}

All the above mentioned studies suggest that the effect of stress on BP and vascular function depends on genetic predisposition to hypertension, duration of stress, age and sex. NO production in the various parts of the HPA axis, SNS and the vasculature may be considerably altered in response to diverse stressors affecting the release of various hormones and autacoids. Despite many discrepancies and contradictions, elevated NO synthesis, especially in the initial phase of stress may be considered a stress-limiting mechanism, facilitating the recovery from stress to the resting levels via attenuation of both GC release and SNS activity as well as by increased NO-dependent vasorelaxation. On the other hand, reduced levels of NO were observed in the later phases of stress and in subjects with genetic predisposition to hypertension, irrespectively, in which reduced NO bioavailability may account for disruption of NO-mediated BP regulatory mechanisms and accentuated SNS and GC effects. Thus NO plays a crucial role in the regulation of the stress systems and thereby in the BP regulation in stress.

\section{Conflict of Interest}

There is no conflict of interest.

\section{Acknowledgements}

We express our thanks to all colleagues from the Institute of Normal and Pathological Physiology, Slovak Academy of Sciences, especially to Dr. M. Gerová for her critical comments and discussion to our studies related to stress. The studies were supported by the Slovak Grant Agency for Science, Grant No. 2/0084/14, the Slovak Research and Development Agency, Grant No. APVV-0523-10 and grant of the Slovak Society of Cardiology. The financial support for infrastructure to accomplish the research work conducted in our laboratory was partially provided by the ITMS 26240120020 - Establishment of the Centre for the Research on Composite Materials for Structural, Engineering and Medical Applications CEKOMAT II.
Abbreviations
$\mathrm{ACh}$ - acetylcholine
ACTH - adrenocorticotropic hormone
$\mathrm{AT}_{1}$ - angiotensin II type 1 receptor
$\mathrm{BH}_{4}$ - tetrahydrobiopterin
cGMP - cyclic guanosine monophosphate
CNS - central nervous system
COX - cyclooxygenase
$\mathrm{CRH}$ - corticotropin releasing hormone
CVDs - cardiovascular diseases
CVS - cardiovascular system
EDCFs - endothelium-derived contracting factors
EDHFs - endothelium-derived hyperpolarizing factors
EDRFs - endothelium-derived relaxing factors
eNO - nitric oxide synthesized by eNOS
eNOS - endothelial nitric oxide synthase
GABA - gamma-aminobutyric acid
GC - glucocorticoids
GR - glucocorticoid receptors
GTPCH1 - guanosine triphosphate cyclohydrolase I
HPA - hypothalamic-pituitary-adrenocortical
$\mathrm{HR}$ - heart rate
iNOS - inducible nitric oxide synthase
L-NAME - $\mathrm{N}^{\mathrm{G}}$-nitro-L-arginine methyl ester
$\mathrm{MAP}$ - mean arterial pressure
$\mathrm{MR}$ - mineralocorticoid receptor
$\mathrm{NA}$ - noradrenaline
NMDA - N-methyl-D-aspartate 


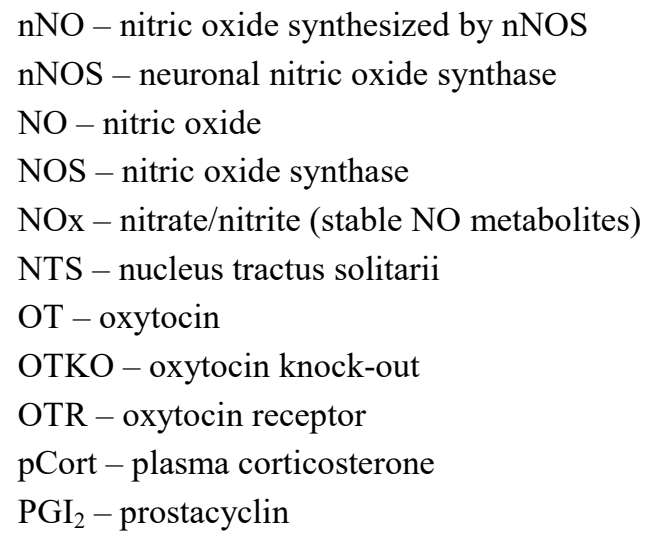

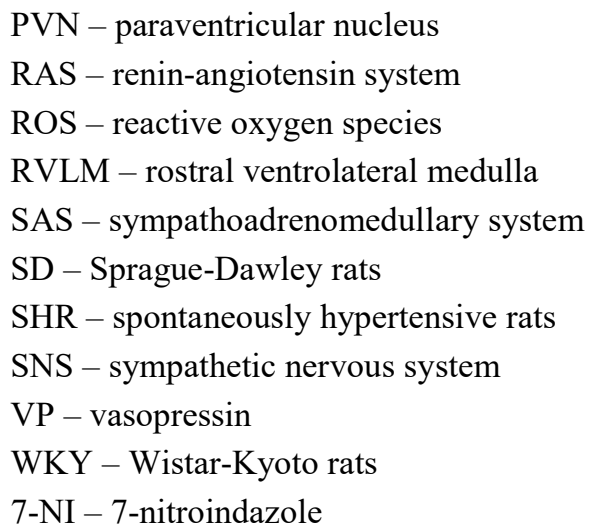

\section{References}

ADDICKS K, BLOCH W, FEELISCH M: Nitric oxide modulates sympathetic neurotransmission at the prejunctional level. Microsc Res Tech 29: 161-168, 1994.

ALASTALO H, RAIKKONEN K, PESONEN AK, OSMOND C, BARKER DJ, HEINONEN K, KAJANTIE E, ERIKSSON JG: Early life stress and blood pressure levels in late adulthood. J Hum Hypertens 27: 90-94, 2013.

ALDERTON WK, COOPER CE, KNOWLES RG: Nitric oxide synthases: structure, function and inhibition. Biochem J 357: 593-615, 2001.

ANDRÉ-PETERSSON L, ENGSTRÖM G, HAGBERG B, JANZON L, STEEN G: Adaptive behavior in stressful situations and stroke incidence in hypertensive men: results from prospective cohort study "men born in 1914" in Malmö, Sweden. Stroke 32: 1712-1720, 2001.

ANDREWS E, JENKINS C, SEACHRIST D, DUNPHY G, ELY D: Social stress increases blood pressure and cardiovascular pathology in a normotensive rat model. Clin Exp Hypertens 25: 85-101, 2003.

ARAS-LOPEZ R, XAVIER FE, FERRER M, BALFAGÓN G: Dexamethasone decreases neuronal nitric oxide release in mesenteric arteries from hypertensive rats through decreased protein kinase C activation. Clin Sci (Lond) 117: 305-312, 2009.

ARMARIO A, LOPEZ-CALDERON A, JOLIN T, BALASCH J: Response of anterior pituitary hormones to chronic stress. The specificity of adaptation. Neurosci Biobehav Rev 10: 245-250, 1986.

BABAL P, PECHANOVA O, BERNATOVA I, STVRTINA S: Chronic inhibition of NO synthesis produces myocardial fibrosis and arterial media hyperplasia. Histol Histopathol 12: 623-629, 1997.

BABIC S, POKUSA M, DANEVOVA V, DING ST, JEZOVA D: Effects of atosiban on stress-related neuroendocrine factors. $J$ Endocrinol 225: 9-17, 2015.

BACHSCHMID MM, SCHILDKNECHT S, MATSUI R, ZEE R, HAEUSSLER D, COHEN RA, PIMENTAL D, LOO BV: Vascular aging: chronic oxidative stress and impairment of redox signaling-consequences for vascular homeostasis and disease. Ann Med 45: 17-36, 2013.

BARBARYAN A, BAILUC SL, PATEL K, RAQEEM MW, THAKUR A, MIRRAKHIMOV AE: An emotional stress as a trigger for reverse Takotsubo cardiomyopathy: a case report and literature review. Am J Case Rep 17: 137-142, 2016.

BAUER ME, PERKS P, LIGHTMAN SL, SHANKS N: Restraint stress is associated with changes in glucocorticoid immunoregulation. Physiol Behav 73: 525-532, 2001.

BECHTOLD AG, PATEL G, HOCHHAUS G, SCHEUER DA: Chronic blockade of hindbrain glucocorticoid receptors reduces blood pressure responses to novel stress and attenuates adaptation to repeated stress. Am J Physiol Regul Integr Comp Physiol 296: R1445-R1454, 2009.

BEHULIAK M, PINTÉROVÁ M, KUNEŠ J, ZICHA J: Vasodilator efficiency of endogenous prostanoids, Ca ${ }^{2+}$ activated $\mathrm{K}^{+}$channels and nitric oxide in rats with spontaneous, salt-dependent or NO-deficient hypertension. Hypertens Res 34: 968-975, 2011. 
BERNATOVA I: The effect of chronic social stress on the production of nitric oxide in the heart and neuroendocrine system of rats with different family history of hypertension (in Slovak). In: Mechanizmy regulácie krvného tlaku a ich poruchy (Mechanisms of blood pressure regulation and their disorders). I BERNATOVA, F KRISTEK, O PECHANOVA, J TÖRÖK (eds), Univerzita Komenského Bratislava, Slovakia, 2006, pp 17-30.

BERNATOVA I: Endothelial dysfunction in experimental models of arterial hypertension: cause or consequence? Biomed Res Int 2014: 598271, 2014.

BERNATOVA I, PECHANOVA O, SIMKO F: Captopril prevents NO-deficient hypertension and left ventricular hypertrophy without affecting nitric oxide synthase activity in rats. Physiol Res 45: 311-316, 1996.

BERNATOVA I, KEY MP, LUCOT JB, MORRIS M: Circadian differences in stress-induced pressor reactivity in mice. Hypertension 40: 768-773, 2002a.

BERNATOVA I, PECHANOVA O, BABAL P, KYSELA S, STVRTINA S, ANDRIANTSITOHAINA R: Wine polyphenols improve cardiovascular remodeling and vascular function in NO-deficient hypertension. $A m J$ Physiol Heart Circ Physiol 282: H942-H948, 2002b.

BERNATOVA I, RIGATTO KV, KEY MP, MORRIS M: Stress-induced pressor and corticosterone responses in oxytocin-deficient mice. Exp Physiol 89: 549-557, 2004.

BERNATOVA I, CSIZMADIOVA Z, KOPINCOVA J, PUZSEROVA A: Vascular function and nitric oxide production in chronic social-stress-exposed rats with various family history of hypertension. $J$ Physiol Pharmacol 58: 487-501, 2007a.

BERNATOVA I, PUZSEROVA A, NAVAROVA J, CSIZMADIOVA Z, ZEMAN M: Crowding-induced alterations in vascular system of Wistar-Kyoto rats: role of nitric oxide. Physiol Res 56: 667-669, $2007 \mathrm{~b}$.

BERNATOVA I, KOPINCOVA J, PUZSEROVA A: Chronic stress deteriorated nitric oxide production in Wistar rats exposed to a low dose of L-NAME. Act Nerv Super Rediviva 52: 200-205, 2010.

BERNÁTOVÁ I, PÚZSEROVÁ A, BALIŠ P, KLUKNAVSKÝ M, ŠESTÁKOVÁ N, BUŠOVÁ D: Differences in delayed stress-induced behavioural and vascular effects in young normotensive and borderline hypertensive rats. In: Eleventh Symposium on Catecholamines and Other Neurotransmitters in Stress. Smolenice Castle, Slovakia, June 20-25, 2015. Bratislava: Ústav Experimentálnej Endokrinológie SAV, 2015, p. 9.

BERNÁTOVÁ I, BALIŠ P, GOGA R, BEHULIAK M, ZICHA J, SEKAJ I: Lack of reactive oxygen species deteriorates blood pressure regulation in acute stress. Physiol Res 65 (Suppl 3): S381-S390, 2016.

BOBROVSKAYA L, BEARD D, BONDARENKO E, BEIG MI, JOBLING P, WALKER FR, DAY TA, NALIVAIKO E: Does exposure to chronic stress influence blood pressure in rats? Auton Neurosci 177: 217-223, 2013.

BONDARENKO ON, BONDARENKO NA, MALYSHEV IY, MANUKHINA EB: Antistress effect of nitric oxide. Biol Bull 28: 387-393, 2001.

BOUZINOVA EV, NORREGAARD R, BOEDTKJER DM, RAZGOVOROVA IA, MOELLER AM, KUDRYAVTSEVA O, WIBORG O, AALKJAER C, MATCHKOV VV: Association between endothelial dysfunction and depression-like symptoms in chronic mild stress model of depression. Psychosom Med 76: 268-276, 2014.

BRIAUD SA, ZHANG BL, SANNAJUST F: Continuous light exposure and sympathectomy suppress circadian rhythm of blood pressure in rats. J Cardiovasc Pharmacol Ther 9: 97-105, 2004.

BRUDER-NASCIMENTO T, CAMPOS DH, CICOGNA AC, CORDELLINI S: Chronic stress improves $\mathrm{NO}^{-}$and $\mathrm{Ca}^{2+}$ flux-dependent vascular function: a pharmacological study. Arq Bras Cardiol 104: 226-233, 2015.

BUGAJSKI J: Social stress adapts signaling pathways involved in stimulation of the hypothalamic-pituitary-adrenal axis. J Physiol Pharmacol 50: 367-379, 1999.

BUGAJSKI J, GADEK-MICHALSKA A, BORYCZ J, GLÓD R: Social stress inhibits the nitric oxide effect on the corticotropin-releasing hormone- but not vasopressin-induced pituitary-adrenocortical responsiveness. Brain Res 817: 220-225, 1999a.

BUGAJSKI J, GADEK-MICHALSKA A, GŁÓD R, BORYCZ J, BUGAJSKI AJ: Blockade of nitric oxide formation impairs adrenergic-induced ACTH and corticosterone secretion. J Physiol Pharmacol 50: 327-334, 1999b.

BUGAJSKI AJ, GADEK-MICHALSKA A, BUGAJSKI J: The involvement of nitric oxide and prostaglandins in the cholinergic stimulation of hypothalamic-pituitary-adrenal response during crowding stress. J Physiol Pharmacol 57: 463-477, 2006. 
CÁBEL M, SMIESKO V, JOHNSON PC: Attenuation of blood flow-induced dilation in arterioles after muscle contraction. Am J Physiol 266: H2114-H2121, 1994.

CACANYIOVA S, KRISTEK F, MALEKOVA M, ONDRIAS K: Effects of chronic neuronal nitric oxide-synthase inhibition on arterial function and structure in spontaneously hypertensive rats. $J$ Physiol Pharmacol 63: 23-28, 2012.

CACANYIOVA S, BERENYIOVA A, MALEKOVA M, KRISTEK F, DOVINOVA I, KRENEK P, PIVACKOVA L, PIFKOVA I: Different vasoactive effects of chronic endothelial and neuronal NO-synthase inhibition in young Wistar rats. J Physiol Biochem 70: 749-760, 2014.

CAGAN S, PAVLOVIC M, BESEDOVA I: Epidemiology and prevention of cardiovascular diseases after 1989. Bratisl Lek Listy 100: 395-404, 1999.

CALLAHAN MF, THORE CR, SUNDBERG DK, GRUBER KA, O'STEEN K, MORRIS M: Excitotoxin paraventricular nucleus lesions: stress and endocrine reactivity and oxytocin mRNA levels. Brain Res 597: 8-15, 1992.

CARDILLO C, KILCOYNE CM, QUYYUMI AA, CANNON RO 3RD, PANZA JA: Role of nitric oxide in the vasodilator response to mental stress in normal subjects. Am J Cardiol 80: 1070-1074, 1997.

CARTER JR, KUPIERS NT, RAY CA: Neurovascular responses to mental stress. $J$ Physiol 564: 321-327, 2005.

CHAN SH, WANG LL, CHAN JY: Differential engagements of glutamate and GABA receptors in cardiovascular actions of endogenous nNOS or iNOS at rostral ventrolateral medulla of rats. Br J Pharmacol 138: 584-593, 2003.

CHEN X, HERBERT J: Regional changes in c-fos expression in the basal forebrain and brainstem during adaptation to repeated stress: correlations with cardiovascular, hypothermic and endocrine responses. Neuroscience 64: 675-685, 1995.

CHENG WH, HO WY, CHANG CF, LU PJ, CHENG PW, YEH TC, HONG LZ, SUN GC, HSIAO M, TSENG CJ: Simvastatin induces a central hypotensive effect via Ras-mediated signalling to cause eNOS up-regulation. Br J Pharmacol 170: 847-858, 2013.

CHIES AB, CORREAA FM, DE ANDRADE CR, ROSA-E-SILVA AA, PEREIRA FC, DE OLIVEIRA AM: Vascular non-endothelial nitric oxide induced by swimming exercise stress in rats. Clin Exp Pharmacol Physiol 30: 951-957, 2003.

CHUNG KK, MARTINEZ M, HERBERT J: Central serotonin depletion modulates the behavioural, endocrine and physiological responses to repeated social stress and subsequent c-fos expression in the brains of male rats. Neuroscience 92: 613-625, 1999.

CORDELLINI S, VASSILIEFF VS: Decreased endothelium-dependent vasoconstriction to noradrenaline in acutestressed rats is potentiated by previous chronic stress: nitric oxide involvement. Gen Pharmacol 30: 79-83, 1998.

CORDELLINI S, NOVO R, LANZA JÚNIOR U: Exposure to stress differential vascular adaptive response in spontaneously hypertensive and Wistar rats: Role of nitric oxide, and prehypertensive and hypertensive states. Life Sci 79: 646-653, 2006.

COX RH, HUBBARD JW, LAWLER JE, SANDERS BJ, MITCHELL VP: Cardiovascular and sympathoadrenal responses to stress in swim-trained rats. J Appl Physiol 58: 1207-1214, 1985.

CRESTANI CC: Emotional stress and cardiovascular complications in animal models: A review of the influence of stress type. Front Physiol 7: 251, 2016. doi: 10.3389/fphys.2016.00251.

DAI FX, SKOPEC J, DIEDERICH A, DIEDERICH D: Prostaglandin $\mathrm{H}_{2}$ and thromboxane $\mathrm{A}_{2}$ are contractile factors in intrarenal arteries of spontaneously hypertensive rats. Hypertension 19: 795-798, 1992.

DAIBER A, STEVEN S, WEBER A, SHUVAEV VV, MUZYKANTOV VR, LAHER I, LI H, LAMAS S, MÜNZEL T: Targeting vascular (endothelial) dysfunction. Br J Pharmacol 2016, doi: 10.1111/bph.13517.

DAMPNEY RA, HORIUCHI J, KILLINGER S, SHERIFF MJ, TAN PS, MCDOWALL LM: Long-term regulation of arterial blood pressure by hypothalamic nuclei: some critical questions. Clin Exp Pharmacol Physiol 32: 419-425, 2005.

DANEVOVA V, KVETNANSKY R, JEZOVA D: Kinetics of oxytocin response to repeated restraint stress and/or chronic cold exposure. Horm Metab Res 45: 845-848, 2013. 
DE OLIVEIRA RM, APARECIDA DEL BEL E, MAMEDE-ROSA ML, PADOVAN CM, DEAKIN JF, GUIMARAES FS: Expression of neuronal nitric oxide synthase mRNA in stress-related brain areas after restraint in rats. Neurosci Lett 289: 123-126, 2000.

DIETZ NM, RIVERA JM, EGGENER SE, FIX RT, WARNER DO, JOYNER MJ: Nitric oxide contributes to the rise in forearm blood flow during mental stress in humans. J Physiol 480: 361-368, 1994.

DIEZ-ROUX AV, NIETO FJ, TYROLER HA, CRUM LD, SZKLO M: Social inequalities and atherosclerosis. The atherosclerosis risk in communities study. Am J Epidemiol 141: 960-972, 1995.

DJORDJEVIĆ J, CVIJIĆ G, DAVIDOVIĆ V: Different activation of ACTH and corticosterone release in response to various stressors in rats. Physiol Res 52: 67-72, 2003.

DLUGOSOVA K, MITASIKOVA M, BERNATOVA I, WEISMANN P, OKRUHLICOVA L: Reduced connexin-43 expression in the aorta of pre-hypertensive rats. Physiol Res 57 (Suppl 2): S23-S29, 2008.

DOBESOVÁ Z, KUNES J, ZICHA J: The altered balance between sympathetic nervous system and nitric oxide in salt hypertensive Dahl rats: ontogenetic and F2 hybrid studies. J Hypertens 20: 945-955, 2002.

DRONJAK S, GAVRILOVIĆ L, FILIPOVIĆ D, RADOJCIĆ MB: Immobilization and cold stress affect sympathoadrenomedullary system and pituitary-adrenocortical axis of rats exposed to long-term isolation and crowding. Physiol Behav 81: 409-415, 2004.

DUCKLES SP, MILLER VM: Hormonal modulation of endothelial NO production. Pflugers Arch 459: 841-851, 2010.

ESCH T, STEFANO GB, FRICCHIONE GL, BENSON H: Stress in cardiovascular diseases. Med Sci Monit 8: RA93RA101, 2002a.

ESCH T, STEFANO GB, FRICCHIONE GL, BENSON H: Stress-related diseases - a potential role for nitric oxide. Med Sci Monit 8: RA103-RA118, 2002 b.

ESLER M, EIKELIS N, SCHLAICH M, LAMBERT G, ALVARENGA M, DAWOOD T, KAYE D, BARTON D, PIER C, GUO L, BRENCHLEY C, JENNINGS G, LAMBERT E: Chronic mental stress is a cause of essential hypertension: presence of biological markers of stress. Clin Exp Pharmacol Physiol 35: 498-502, 2008.

FALARDEAU P, MARTINEAU A: Prostaglandin $I_{2}$ and glucocorticoid-induced rise in arterial pressure in the rat. J Hypertens 7: 625-632, 1989.

FAVERO G, PAGANELLI C, BUFFOLI B, RODELLA LF, REZZANI R: Endothelium and its alterations in cardiovascular diseases: life style intervention. Biomed Res Int 2014: 801896, 2014.

FISHER LD, TUCKER DC: Air jet noise exposure rapidly increases blood pressure in young borderline hypertensive rats. J Hypertens 9: 275-282, 1991.

FITZGERALD SM, BRANDS MW: Hypertension in L-NAME-treated diabetic rats depends on an intact sympathetic nervous system. Am J Physiol Regul Integr Comp Physiol 282: R1070-R1076, 2002.

FLEMING I, BAUM A, DAVIDSON LM, RECTANUS E, MCARDLE S: Chronic stress as a factor in physiologic reactivity to challenge. Health Psychol 6: 221-237, 1987.

FOKKEMA DS, KOOLHAAS JM, VAN DER MEULEN J, SCHOEMAKER R: Social stress induced pressure breathing and consequent blood pressure oscillation. Life Sci 38: 569-575, 1986.

FRANCO GP, DE BARROS AL, NOGUEIRA-MARTINS LA, MICHEL JL: Stress influence on genesis, onset and maintenance of cardiovascular diseases: literature review. $J$ Adv Nurs 43: 548-554, 2003.

FUCHS LC, HOQUE AM, CLARKE NL: Vascular and hemodynamic effects of behavioral stress in borderline hypertensive and Wistar-Kyoto rats. Am J Physiol 274: R375-R382, 1998.

GADEK-MICHALSKA A, BUGAJSKI J: Nitric oxide mediates the interleukin-1beta- and nicotine-induced hypothalamic-pituitary-adrenocortical response during social stress. J Physiol Pharmacol 56: 491-503, 2005.

GALLEANO M, BERNATOVA I, PUZSEROVA A, BALIS P, SESTAKOVA N, PECHANOVA O, FRAGA CG: (-)-Epicatechin reduces blood pressure and improves vasorelaxation in spontaneously hypertensive rats by NO-mediated mechanism. IUBMB Life 65: 710-715, 2013.

GAO SF, LU YR, SHI LG, WU XY, SUN B, FU XY, LUO JH, BAO AM: Nitric oxide synthase and nitric oxide alterations in chronically stressed rats: a model for nitric oxide in major depressive disorder. Psychoneuroendocrinology 47: 136-140, 2014. 
GARAFOVA A, PENESOVA A, CIZMAROVA E, MARKO A, VLCEK M, JEZOVA D: Cardiovascular and sympathetic responses to a mental stress task in young patients with hypertension and/or obesity. Physiol Res 63 (Suppl 4): S459-S467, 2014.

GAVRILOVIC L, DRONJAK S: Sympatho-adrenomedullary system responses to various chronic stress situations. Jugoslov Med Biochem 25: 11-15, 2006.

GELSEMA AJ, SCHOEMAKER RG, RUZICKA M, COPELAND NE: Cardiovascular effects of social stress in borderline hypertensive rats. J Hypertens 12: 1019-1028, 1994.

GEROVÁ M: Nitric oxide-compromised hypertension: facts and enigmas. Physiol Res 49: 27-35, 2000.

GEROVÁ M, MASÁNOVÁ C, PAVLÁSEK J: Inhibition of NO synthase in the posterior hypothalamus increases blood pressure in the rat. Physiol Res 44: 131-134, 1995.

GEROVÁ M, TÖRÖK J, PECHÁŇOVÁ O, MATUSKOVÁ J: Rilmenidine prevents blood pressure increase in rats with compromised nitric oxide production. Acta Pharmacol Sin 25: 1640-1646, 2004.

GHIADONI L, DONALD AE, CROPLEY M, MULLEN MJ, OAKLEY G, TAYLOR M, O'CONNOR G, BETTERIDGE J, KLEIN N, STEPTOE A, DEANFIELD JE: Mental stress induces transient endothelial dysfunction in humans. Circulation 102: 2473-2478, 2000.

GHIADONI L, TADDEI S, VIRDIS A: Hypertension and endothelial dysfunction: therapeutic approach. Curr Vasc Pharmacol 10: 42-60, 2012.

GIBBS DM: Immunoneutralization of oxytocin attenuates stress-induced corticotropin secretion in the rat. Regul Pept 12: 273-277, 1985.

GOLBIDI S, FRISBEE JC, LAHER I: Chronic stress impacts the cardiovascular system: animal models and clinical outcomes. Am J Physiol Heart Circ Physiol 308: H1476-H1498, 2015.

GOODWIN JE, GELLER DS: Glucocorticoid-induced hypertension. Pediatr Nephrol 27: 1059-1066, 2012.

GOODWIN JE, ZHANG J, GONZALEZ D, ALBINSSON S, GELLER DS: Knockout of the vascular endothelial glucocorticoid receptor abrogates dexamethasone-induced hypertension. J Hypertens 29: 1347-1356, 2011.

GRASSI G, RAM VS: Evidence for a critical role of the sympathetic nervous system in hypertension. $J$ Am Soc Hypertens 10: 457-466, 2016.

GRIPPO AJ, MOFFITT JA, JOHNSON AK: Cardiovascular alterations and autonomic imbalance in an experimental model of depression. Am J Physiol Regul Integr Comp Physiol 282: R1333-R1341, 2002.

GRUNFELD JP, ELOY L, MOURA AM, GANEVAL D, RAMOS-FRENDO B, WORCEL M: Effects of antiglucocorticoids on glucocorticoid hypertension in the rat. Hypertension 7: 292-299, 1985.

GUIX FX, URIBESALGO I, COMA M, MUNOZ FJ: The physiology and pathophysiology of nitric oxide in the brain. Prog Neurobiol 76: 126-152, 2005.

GULATI K, RAY A, MASOOD A, VIJAYAN VK: Involvement of nitric oxide (NO) in the regulation of stress susceptibility and adaptation in rats. Indian J Exp Biol 44: 809-815, 2006.

GULATI K, JOSHI JC, RAY A: Recent advances in stress research: Focus on nitric oxide. Eur J Pharmacol 765 : 406-414, 2015.

GUTKOWSKA J, JANKOWSKI M, MUKADDAM-DAHER S, MCCANN SM: Oxytocin is a cardiovascular hormone. Braz J Med Biol Res 33: 625-633, 2000.

HARRAP SB, LOUIS WJ, DOYLE AE: Failure of psychosocial stress to induce chronic hypertension in the rat. J Hypertens 2: 653-662, 1984.

HASHIGUCHI H, YE SH, MORRIS M, ALEXANDER N: Single and repeated environmental stress: effect on plasma oxytocin, corticosterone, catecholamines, and behavior. Physiol Behav 61: 731-736, 1997.

HATTON DC, DEMERRITT J, COSTE SC, MCCARRON DA: Stress-induced hypertension in the borderline hypertensive rat: stimulus duration. Physiol Behav 53: 635-641, 1993.

HELMINEN A, RANKINEN T, MERCURI M, RAURAMAA R: Carotid atherosclerosis in middle-aged men. Relation to conjugal circumstances and social support. Scand J Soc Med 23: 167-172, 1995.

HENRY JP, STEPHENS-LARSON P: Reduction of chronic psychosocial hypertension in mice by decaffeinated tea. Hypertension 6: 437-444, 1984.

HENRY JP, LIU YY, NADRA WE, QIAN CG, MORMEDE P, LEMAIRE V, ELY D, HENDLEY ED: Psychosocial stress can induce chronic hypertension in normotensive strains of rats. Hypertension 21: 714-723, 1993. 
HIJMERING ML, STROES ES, OLIJHOEK J, HUTTEN BA, BLANKESTIJN PJ, RABELINK TJ: Sympathetic activation markedly reduces endothelium-dependent, flow-mediated vasodilation. $J$ Am Coll Cardiol 39: 683-688, 2002.

HOJNÁ S, KADLECOVÁ M, DOBESOVÁ Z, VALOUSKOVÁ V, ZICHA J, KUNES J: The participation of brain NO synthase in blood pressure control of adult spontaneously hypertensive rats. Mol Cell Biochem 297: 21-29, 2007.

HOJNÁ S, KUNEŠ J, ZICHA J: Alterations of NO synthase isoforms in brain and kidney of rats with genetic and salt hypertension. Physiol Res 59: 997-1009, 2010.

HOLÉCYOVÁ A, GEROVÁ M, SMIESKO V, DOLEZEL S: Contractility of the rabbit abdominal aorta 4 days after endothelium denudation. J Vasc Res 30: 224-230, 1993.

HOLÉCYOVÁ A, TÖRÖK J, BERNÁTOVÁ I, PECHÁNOVÁ O: Restriction of nitric oxide rather than elevated blood pressure is responsible for alterations of vascular responses in nitric oxide-deficient hypertension. Physiol Res 45: 317-321, 1996.

HORVATHOVA M, ZITNANOVA I, KRALOVICOVA Z, BALIS P, PUZSEROVA A, MUCHOVA J, KLUKNAVSKY M, DURACKOVA Z, BERNATOVA I: Sex differences in the blood antioxidant defense system in juvenile rats with various genetic predispositions to hypertension. Hypertens Res 39: 64-69, 2016.

HOVSEPIAN K, AL'ABSI M, ERTIN E, KAMARCK T, NAKAJIMA M, KUMAR S: Stress: towards a gold standard for continuous stress assessment in the mobile environment. Proc ACM Int Conf Ubiquitous Comput 2015: 493-504, 2015.

HSIEH HJ, LIU CA, HUANG B, TSENG AH, WANG DL: Shear-induced endothelial mechanotransduction: the interplay between reactive oxygen species (ROS) and nitric oxide (NO) and the pathophysiological implications. J Biomed Sci 21: 3, 2014.

IHRIG M, DANGLER CA, FOX JG: Mice lacking inducible nitric oxide synthase develop spontaneous hypercholesterolaemia and aortic atheromas. Atherosclerosis 156: 103-107, 2001.

ISINGRINI E, SURGET A, BELZUNG C, FRESLON JL, FRISBEE J, O'DONNELL J, CAMUS V, D'AUDIFFRET A: Altered aortic vascular reactivity in the unpredictable chronic mild stress model of depression in mice: UCMS causes relaxation impairment to ACh. Physiol Behav 103: 540-546, 2011.

JEZOVA D, SKULTETYOVA I, TOKAREV DI, BAKOS P, VIGAS M: Vasopressin and oxytocin in stress. Ann NY Acad Sci 771: 192-203, 1995.

JEZOVA D, KRISTOVA V, SLAMOVA J, MLYNARIK M, PIRNIK Z, KISS A, KRISKA M: Stress-induced rise in endothelaemia, von Willebrand factor and hypothalamic-pituitary-adrenocortical axis activation is reduced by pretreatment with pentoxifylline. J Physiol Pharmacol 54: 329-338, 2003.

KAPLAN JR, MANUCK SB, CLARKSON TB, LUSSO FM, TAUB DM: Social status, environment, and atherosclerosis in cynomolgus monkeys. Arteriosclerosis 2: 359-368, 1982.

KAPLAN JR, MANUCK SB, CLARKSON TB, LUSSO FM, TAUB DM, MILLER EW: Social stress and atherosclerosis in normocholesterolemic monkeys. Science 220: 733-735, 1983.

KARANTH S, LYSON K, MCCANN SM: Role of nitric oxide in interleukin 2-induced corticotropin-releasing factor release from incubated hypothalami. Proc Natl Acad Sci U S A 90: 3383-3387, 1993.

KATUSIC ZS, SHEPHERD JT, VANHOUTTE PM: Oxytocin causes endothelium-dependent relaxations of canine basilar arteries by activating $\mathrm{V}_{1}$-vasopressinergic receptors. J Pharmacol Exp Ther 236: 166-170, 1986.

KAUSHIK RM, MAHAJAN SK, RAJESH V, KAUSHIK R: Stress profile in essential hypertension. Hypertens Res 27: 619-624, 2004.

KAWA T, TAKEDA K, HARADA S, HATTA T, MORIGUCHI J, MIKI S, MORIMOTO S, ITOH H, NAKATA T, SASAKI S, NAKAGAWA M: The role of the hypothalamic nitric oxide in the pressor responses elicited by acute environmental stress in awake rats. Life Sci 71: 1429-1438, 2002.

KELLER A, LITZELMAN K, WISK LE, MADDOX T, CHENG ER, CRESWELL PD, WITT WP: Does the perception that stress affects health matter? The association with health and mortality. Health Psychol 31: 677-684, 2012.

KELLEROVÁ E: The effect of food intake on cardiovascular function. Changes in the blood pressure and pulse frequency in neonates and infants during suckling (in Slovak). Cesk Fysiol 42: 99-102, 1993. 
KELLEROVÁ E: Variability and reactive changes of the peripheral blood flow, blood pressure and of the electrical behavior of the heart. Act Nerv Super Rediviva 55: 113-124, 2013.

KIMURA Y, HIROOKA Y, SAGARA Y, ITO K, KISHI T, SHIMOKAWA H, TAKESHITA A, SUNAGAWA K: Overexpression of inducible nitric oxide synthase in rostral ventrolateral medulla causes hypertension and sympathoexcitation via an increase in oxidative stress. Circ Res 96: 252-260, 2005.

KIMURA Y, HIROOKA Y, KISHI T, ITO K, SAGARA Y, SUNAGAWA K: Role of inducible nitric oxide synthase in rostral ventrolateral medulla in blood pressure regulation in spontaneously hypertensive rats. Clin Exp Hypertens 31: 281-286, 2009.

KIRKUP W, MERRICK DW: A matter of life and death: population mortality and football results. $J$ Epidemiol Community Health 57: 429-432, 2003.

KISHI T, HIROOKA Y, SAKAI K, SHIGEMATSU H, SHIMOKAWA H, TAKESHITA A: Overexpression of eNOS in the RVLM causes hypotension and bradycardia via GABA release. Hypertension 38: 896-901, 2001.

KISHIMOTO J, TSUCHIYA T, EMSON PC, NAKAYAMA Y: Immobilization-induced stress activates neuronal nitric oxide synthase (nNOS) mRNA and protein in hypothalamic-pituitary-adrenal axis in rats. Brain Res $\mathbf{7 2 0}$ : 159-171, 1996.

KISS A, JURKOVICOVA D, JEZOVA D, KRIZANOVA O: Changes in angiotensin $\mathrm{AT}_{1}$ receptor mRNA levels in the rat brain after immobilization stress and inhibition of central nitric oxide synthase. Endocr Regul 35: 65-70, 2001.

KLONER RA: The "Merry Christmas Coronary" and "Happy New Year Heart Attack" phenomenon. Circulation 110: 3744-3745, 2004.

KOPINCOVA J, PUZSEROVA A, BERNATOVA I: L-NAME in the cardiovascular system - nitric oxide synthase activator? Pharmacol Rep 64: 511-520, 2012.

KORNER P, BOBIK A, ODDIE C, FRIBERG P: Sympathoadrenal system is critical for structural changes in genetic hypertension. Hypertension 22: 243-252, 1993.

KRISTEK F, FÁBEROVÁ V, VARGA I: Long-term effect of molsidomine and pentaerythrityl tetranitrate on cardiovascular system of spontaneously hypertensive rats. Physiol Res 52: 709-717, 2003.

KRISTEK F, DROBNA M, CACANYIOVA S: Different effects of 7-nitroindazole and L-NAME administered both individually and together on the cardiovascular system of the rat. Physiol Res 64: 1-10, 2015.

KRISTOVA V, KISS A, PIRNIK Z, KRISKA M, JEZOVA D: Effect of pentoxifylline on endothelaemia and hypothalamic-pituitary-adrenocortical axis activation in female rats under stress exposure. Gen Physiol Biophys 25: 81-89, 2006.

KRIZANOVÁ O, KISS A, ZÁCIKOVÁ L, JEZOVÁ D: Nitric oxide synthase mRNA levels correlate with gene expression of angiotensin II type-1 but not type-2 receptors, renin or angiotensin converting enzyme in selected brain areas. Physiol Res 50: 473-480, 2001.

KUNES J, HOJNA S, KADLECOVA M, DOBESOVA Z, RAUCHOVA H, VOKURKOVA M, LOUKOTOVA J, PECHANOVA O, ZICHA J: Altered balance of vasoactive systems in experimental hypertension: the role of relative NO deficiency. Physiol Res 53 (Suppl 1): S23-S34, 2004.

KVETNANSKÝ R, PACÁK K, TOKAREV D, JELOKOVÁ J, JEZOVÁ D, RUSNÁK M: Chronic blockade of nitric oxide synthesis elevates plasma levels of catecholamines and their metabolites at rest and during stress in rats. Neurochem Res 22: 995-1001, 1997.

KVETNANSKÝ R, PACÁK K, SABBAN EL, KOPIN IJ, GOLDSTEIN DS: Stressor specificity of peripheral catecholaminergic activation. Adv Pharmacol 42: 556-560, 1998.

KWIECIEN S, PAWLIK MW, BRZOZOWSKI T, KONTUREK PC, SLIWOWSKI Z, PAWLIK WW, KONTUREK SJ: Nitric oxide (NO)-releasing aspirin and (NO) donors in protection of gastric mucosa against stress. J Physiol Pharmacol 59 (Suppl 2): 103-115, 2008.

KYSELÁ S, TÖRÖK J: The role of endothelial nitric oxide in neurogenic contractions of the carotid artery in rabbits during cooling (in Slovak). Bratisl Lek Listy 98: 80-85, 1997.

LACY CR, CONTRADA RJ, ROBBINS ML, TANNENBAUM AK, MOREYRA AE, CHELTON S, KOSTIS JB: Coronary vasoconstriction induced by mental stress (simulated public speaking). Am J Cardiol 75: 503-505, 1995. 
LAWLER JE, BARKER GF, HUBBARD JW, SCHAUB RG: Pathophysiological changes associated with stressinduced hypertension in the borderline hypertensive rat. Clin Sci (Lond) 59 (Suppl 6): 307s-310s, 1980.

LAWLER JE, BARKER GF, HUBBARD JW, SCHAUB RG: Effects of stress on blood pressure and cardiac pathology in rats with borderline hypertension. Hypertension 3: 496-505, 1981.

LEE RM, BORKOWSKI KR, LEENEN FH, TSOPORIS J, COUGHLIN M: Combined effect of neonatal sympathectomy and adrenal demedullation on blood pressure and vascular changes in spontaneously hypertensive rats. Circ Res 69: 714-721, 1991.

LEE S, KIM CK, RIVIER C: Nitric oxide stimulates ACTH secretion and the transcription of the genes encoding for NGFI-B, corticotropin-releasing factor, corticotropin-releasing factor receptor type 1, and vasopressin in the hypothalamus of the intact rat. $J$ Neurosci 19: 7640-7647, 1999.

LEMAIRE V, MORMEDE P: Telemetered recording of blood pressure and heart rate in different strains of rats during chronic social stress. Physiol Behav 58: 1181-1188, 1995.

LEO MD, KANDASAMY K, SUBRAMANI J, TANDAN SK, KUMAR D: Involvement of inducible nitric oxide synthase and dimethyl arginine dimethylaminohydrolase in $\mathrm{N}^{\omega}$-nitro-L-arginine methyl ester (L-NAME)induced hypertension. Cardiovasc Pathol 24: 49-55, 2015.

LEZA JC, SALAS E, SAWICKI G, RUSSELL JC, RADOMSKI MW: The effects of stress on homeostasis in JCR-LA-cp rats: the role of nitric oxide. J Pharmacol Exp Ther 286: 1397-1403, 1998.

LI SG, LAWLER JE, RANDALL DC, BROWN DR: Sympathetic nervous activity and arterial pressure responses during rest and acute behavioral stress in SHR versus WKY rats. J Auton Nerv Syst 62: 147-154, 1997.

LÍŠKOVÁ S, PETROVÁ M, KAREN P, KUNEŠ J, ZICHA J: Effects of aging and hypertension on the participation of endothelium-derived constricting factor (EDCF) in norepinephrine-induced contraction of rat femoral artery. Eur J Pharmacol 667: 265-270, 2011.

LIU Y, TSUCHIHASHI T, KAGIYAMA S, MATSUMURA K, ABE I, FUJISHIMA M: Central and peripheral mechanisms involved in hypertension induced by chronic inhibition of nitric oxide synthase in rats. J Hypertens 16: 1165-1173, 1998.

LIU Y, MLADINOV D, PIETRUSZ JL, USA K, LIANG M: Glucocorticoid response elements and 11 betahydroxysteroid dehydrogenases in the regulation of endothelial nitric oxide synthase expression. Cardiovasc Res 81: 140-147, 2009.

LOICHOT C, KRIEGER JP, DE JONG W, NISATO D, IMBS JL, BARTHELMEBS M: High concentrations of oxytocin cause vasoconstriction by activating vasopressin $\mathrm{V}_{1 \mathrm{~A}}$ receptors in the isolated perfused rat kidney. Naunyn Schmiedebergs Arch Pharmacol 363: 369-375, 2001.

MALYSHEV IY, MANUKHINA EB: Stress, adaptation, and nitric oxide. Biochemistry (Mosc) 63: 840-853, 1998.

MANCIA G, FAGARD R, NARKIEWICZ K, REDON J, ZANCHETTI A, BÖHM M, CHRISTIAENS T, CIFKOVA R, DE BACKER G, DOMINICZAK A, ET AL.: 2013 ESH/ESC Guidelines for the management of arterial hypertension: the Task Force for the management of arterial hypertension of the European Society of Hypertension (ESH) and of the European Society of Cardiology (ESC). Eur Heart J 34: 2159-2219, 2013.

MANCUSO C, NAVARRA P, PREZIOSI P: Roles of nitric oxide, carbon monoxide, and hydrogen sulfide in the regulation of the hypothalamic-pituitary-adrenal axis. $J$ Neurochem 113: 563-575, 2010.

MANSI JA, DROLET G: Chronic stress induces sensitization in sympathoadrenal responses to stress in borderline hypertensive rats. Am J Physiol 272: R813-R820, 1997.

MANUCK SB, KAPLAN JR, MATTHEWS KA: Behavioral antecedents of coronary heart disease and atherosclerosis. Arteriosclerosis 6: 2-14, 1986.

MARRERO AF, AL'ABSI M, PINCOMB GA, LOVALLO WR: Men at risk for hypertension show elevated vascular resistance at rest and during mental stress. Int J Psychophysiol 25: 185-192, 1997.

MCDOUGALL SJ, PAULL JR, WIDDOP RE, LAWRENCE AJ: Restraint stress: differential cardiovascular responses in Wistar-Kyoto and spontaneously hypertensive rats. Hypertension 35: 126-129, 2000.

MCEWEN BS: Stress, adaptation, and disease. Allostasis and allostatic load. Ann N Y Acad Sci 840: 33-44, 1998.

MCEWEN BS: Physiology and neurobiology of stress and adaptation: central role of the brain. Physiol Rev 87: 873-904, 2007. 
MILLER ME, DAVIDGE ST, MITCHELL BF: Oxytocin does not directly affect vascular tone in vessels from nonpregnant and pregnant rats. Am J Physiol Heart Circ Physiol 282: H1223-H1228, 2002.

MITCHELL BM, DORRANCE AM, MACK EA, WEBB RC: Glucocorticoids decrease GTP cyclohydrolase and tetrahydrobiopterin-dependent vasorelaxation through glucocorticoid receptors. $J$ Cardiovasc Pharmacol 43: 8-13, 2004.

MOLNAR GA, LINDSCHAU C, DUBROVSKA G, MERTENS PR, KIRSCH T, QUINKLER M, GOLLASCH M, WRESCHE S, LUFT FC, MULLER DN, FIEBELER A: Glucocorticoid-related signaling effects in vascular smooth muscle cells. Hypertension 51: 1372-1378, 2008.

MOREIRA JD, PERNOMIAN L, GOMES MS, PERNOMIAN L, MOREIRA RP, DO PRADO AF, DA SILVA CH, DE OLIVEIRA AM: Acute restraint stress increases carotid reactivity in type-I diabetic rats by enhancing Nox4/NADPH oxidase functionality. Eur J Pharmacol 765: 503-516, 2015.

MOREIRA JD, PERNOMIAN L, GOMES MS, MOREIRA RP, DO PRADO AF, DA SILVA CH, DE OLIVEIRA AM: Enhanced nitric oxide generation from nitric oxide synthases as the cause of increased peroxynitrite formation during acute restraint stress: Effects on carotid responsiveness to angiotensinergic stimuli in type-1 diabetic rats. Eur J Pharmacol 783: 11-22, 2016.

MORISHITA T, TSUTSUI M, SHIMOKAWA H, SABANAI K, TASAKI H, SUDA O, NAKATA S, TANIMOTO A, WANG KY, UETA Y, SASAGURI Y, NAKASHIMA Y, YANAGIHARA N: Nephrogenic diabetes insipidus in mice lacking all nitric oxide synthase isoforms. Proc Natl Acad Sci U S A 102: 10616-10621, 2005.

MORRIS M, LI P, BARRETT C, CALLAHAN MF: Oxytocin antisense reduces salt intake in the baroreceptordenervated rat. Regul Pept 59: 261-266, 1995.

MOSTOFSKY E, MACLURE M, SHERWOOD JB, TOFLER GH, MULLER JE, MITTLEMAN MA: Risk of acute myocardial infarction after the death of a significant person in one's life: the Determinants of Myocardial Infarction Onset Study. Circulation 125: 491-496, 2012.

MRAVEC B, ONDICOVA K, VALASKOVA Z, GIDRON Y, HULIN I: Neurobiological principles in the etiopathogenesis of disease: when diseases have a head. Med Sci Monit 15: RA6-RA16, 2009.

MULLER JR, LE KM, HAINES WR, GAN Q, KNUEPFER MM: Hemodynamic response pattern predicts susceptibility to stress-induced elevation in arterial pressure in the rat. Am J Physiol Regul Integr Comp Physiol 281: R31-R37, 2001.

MYSLIVECEK J, KVETNANSKÝ R: The effects of stress on muscarinic receptors. Heterologous receptor regulation: yes or no? Auton Autacoid Pharmacol 26: 235-251, 2006.

NALIVAIKO E: Animal models of psychogenic cardiovascular disorders: what we can learn from them and what we cannot. Clin Exp Pharmacol Physiol 38: 115-125, 2011.

NAVARRO-OLIVEIRA CM, VASSILIEFF VS, CORDELLINI S: The sympathetic adrenomedullary system, but not the hypothalamic-pituitary-adrenal axis, participates in aorta adaptive response to stress: nitric oxide involvement. Auton Neurosci 83: 140-147, 2000.

NEVES VJ, MOURA MJ, TAMASCIA ML, FERREIRA R, SILVA NS, COSTA R, MONTEMOR PL, NARVAES EA, BERNARDES CF, NOVAES PD, MARCONDES FK: Proatherosclerotic effects of chronic stress in male rats: altered phenylephrine sensitivity and nitric oxide synthase activity of aorta and circulating lipids. Stress 12: 320-327, 2009.

NICKEL T, DEUTSCHMANN A, HANSSEN H, SUMMO C, WILBERT-LAMPEN U: Modification of endothelial biology by acute and chronic stress hormones. Microvasc Res 78: 364-369, 2009.

OHLIN B, NILSSON PM, NILSSON JA, BERGLUND G: Chronic psychosocial stress predicts long-term cardiovascular morbidity and mortality in middle-aged men. Eur Heart J 25: 867-873, 2004.

OKAMOTO K, NOSAKA S, YAMORI Y, MATSUMOTO M: Participation of neural factor in the pathogenesis of hypertension in the spontaneously hypertensive rat. Jpn Heart J 8: 168-180, 1967.

OKRUHLICOVA L, DLUGOSOVA K, MITASIKOVA M, BERNATOVA I: Ultrastructural characteristics of aortic endothelial cells in borderline hypertensive rats exposed to chronic social stress. Physiol Res 57 (Suppl 2): S31-S37, 2008. 
ONDREJCAKOVA M, BAKOS J, GARAFOVA A, KOVACS L, KVETNANSKY R, JEZOVA D: Neuroendocrine and cardiovascular parameters during simulation of stress-induced rise in circulating oxytocin in the rat. Stress 13: 314-322, 2010.

ORLANDO GF, LANGNAESE K, SCHULZ C, WOLF G, ENGELMANN M: Neuronal nitric oxide synthase gene inactivation reduces the expression of vasopressin in the hypothalamic paraventricular nucleus and of catecholamine biosynthetic enzymes in the adrenal gland of the mouse. Stress 11: 42-51, 2008.

OSHIKAWA S, TANOUE A, KOSHIMIZU TA, KITAGAWA Y, TSUJIMOTO G: Vasopressin stimulates insulin release from islet cells through $\mathrm{V}_{\mathrm{lb}}$ receptors: a combined pharmacological/knockout approach. Mol Pharmacol 65: 623-629, 2004.

PACÁK K, PALKOVITS M: Stressor specificity of central neuroendocrine responses: implications for stress-related disorders. Endocr Rev 22: 502-548, 2001.

PACÁK K, YADID G, JAKAB G, LENDERS JW, KOPIN IJ, GOLDSTEIN DS: In vivo hypothalamic release and synthesis of catecholamines in spontaneously hypertensive rats. Hypertension 22: 467-478, 1993.

PACAK K, BAFFI JS, KVETNANSKY R, GOLDSTEIN DS, PALKOVITS M: Stressor-specific activation of catecholaminergic systems: implications for stress-related hypothalamic-pituitary-adrenocortical responses. Adv Pharmacol 42: 561-564, 1998.

PANZA JA, CASINO PR, KILCOYNE CM, QUYYUMI AA: Role of endothelium-derived nitric oxide in the abnormal endothelium-dependent vascular relaxation of patients with essential hypertension. Circulation 87: 1468-1474, 1993.

PARRA L, FUENTES JA, ALSASUA A: Vascular alterations in rats with high blood pressure induced by social deprivation stress. Life Sci 55: 669-675, 1994.

PAULIS L, LÍSKOVÁ S, PINTÉROVÁ M, DOBESOVÁ Z, KUNES J, ZICHA J: Nifedipine-sensitive noradrenergic vasoconstriction is enhanced in spontaneously hypertensive rats: the influence of chronic captopril treatment. Acta Physiol (Oxf) 191: 255-266, 2007.

PAULIS L, ZICHA J, KUNES J, HOJNA S, BEHULIAK M, CELEC P, KOJSOVA S, PECHANOVA O, SIMKO F: Regression of L-NAME-induced hypertension: the role of nitric oxide and endothelium-derived constricting factor. Hypertens Res 31: 793-803, 2008.

PAULIS L, BECKER ST, LUCHT K, SCHWENGEL K, SLAVIC S, KASCHINA E, THÖNE-REINEKE C, DAHLÖF B, BAULMANN J, UNGER T, STECKELINGS UM: Direct angiotensin II type 2 receptor stimulation in $\mathrm{N}^{\omega}$-nitro-L-arginine-methyl ester-induced hypertension: the effect on pulse wave velocity and aortic remodeling. Hypertension 59: 485-492, 2012.

PAYNE JA, RECKELHOFF JF, KHALIL RA: Role of oxidative stress in age-related reduction of NO-cGMP-mediated vascular relaxation in SHR. Am J Physiol Regul Integr Comp Physiol 285: R542-R551, 2003.

PECHANOVA O, BERNATOVA I, BABAL P, MARTINEZ MC, KYSELA S, STVRTINA S, ANDRIANTSITOHAINA R: Red wine polyphenols prevent cardiovascular alterations in L-NAME-induced hypertension. J Hypertens 22: 1551-1559, 2004a.

PECHÁŇOVÁ O, DOBEŠOVÁ Z, ČEJKA J, KUNEŠ J, ZICHA J: Vasoactive systems in L-NAME hypertension: the role of inducible NO synthase. J Hypertens 22: 167-173, $2004 \mathrm{~b}$.

PECHÁNOVÁ O, VARGA ZV, CEBOVÁ M, GIRICZ Z, PACHER P, FERDINANDY P: Cardiac NO signalling in the metabolic syndrome. Br J Pharmacol 172: 1415-1433, 2015.

PENESOVA A, RADIKOVA Z, CIZMAROVA E, KVETNANSKÝ R, BLAZICEK P, VLCEK M, KOSKA J, VIGAS M: The role of norepinephrine and insulin resistance in an early stage of hypertension. Ann NY Acad Sci 1148: 490-494, 2008.

PEPPA M, KRANIA M, RAPTIS SA: Hypertension and other morbidities with Cushing's syndrome associated with corticosteroids: a review. Integr Blood Press Control 4: 7-16, 2011.

PETTERSSON K, BEJNE B, BJÖRK H, STRAWN WB, BONDJERS G: Experimental sympathetic activation causes endothelial injury in the rabbit thoracic aorta via beta 1-adrenoceptor activation. Circ Res 67: 1027-1034, 1990.

PEULER JD, SCOTTI MA, PHELPS LE, MCNEAL N, GRIPPO AJ: Chronic social isolation in the prairie vole induces endothelial dysfunction: implications for depression and cardiovascular disease. Physiol Behav 106: 476-484, 2012. 
PICKERING TG: Reflections in hypertension: work and blood pressure. J Clin Hypertens (Greenwich) 6: 403-405, 2004.

PINTÉROVÁ M, KAREN P, KUNES J, ZICHA J: Role of nifedipine-sensitive sympathetic vasoconstriction in maintenance of high blood pressure in spontaneously hypertensive rats: effect of Gi-protein inactivation by pertussis toxin. J Hypertens 28: 969-978, 2010.

PLOCHOCKA-ZULINSKA D, KRUKOFF TL: Increased gene expression of neuronal nitric oxide synthase in brain of adult spontaneously hypertensive rats. Brain Res Mol Brain Res 48: 291-297, 1997.

PROVENCHER PH, SALTIS J, FUNDER JW: Glucocorticoids but not mineralocorticoids modulate endothelin-1 and angiotensin II binding in SHR vascular smooth muscle cells. J Steroid Biochem Mol Biol 52: 219-225, 1995.

PUZSEROVA A, BERNATOVA I: Chronic social stress increases nitric oxide-dependent vasorelaxation in normotensive rats. Interdiscip Toxicol 3: 109-117, 2010.

PUZSEROVA A, CSIZMADIOVA Z, ANDRIANTSITOHAINA R, BERNATOVA I: Vascular effects of red wine polyphenols in chronic stress-exposed Wistar-Kyoto rats. Physiol Res 55 (Suppl 1): S39-S47, 2006.

PUZSEROVA A, TÖRÖK J, SOTNIKOVA R, ZEMANCIKOVA A, BERNATOVA I: Reactivity of the mesenteric bed arteries of normotensive rats exposed to chronic social stress. Gen Physiol Biophys 31: 279-290, 2012.

PUZSEROVA A, KOPINCOVA J, SLEZAK P, BALIS P, BERNATOVA I: Endothelial dysfunction in femoral artery of the hypertensive rats is nitric oxide independent. Physiol Res 62: 615-629, 2013a.

PUZSEROVA A, SLEZAK P, BALIS P, BERNATOVA I: Long-term social stress induces nitric oxide-independent endothelial dysfunction in normotensive rats. Stress 16: 331-339, $2013 \mathrm{~b}$.

PUZSEROVA A, ILOVSKA V, BALIS P, SLEZAK P, BERNATOVA I: Age-related alterations in endothelial function of femoral artery in young SHR and WKY rats. Biomed Res Int 2014: 658479, 2014.

QUALY JM, WESTFALL TC: Release of norepinephrine from the paraventricular hypothalamic nucleus of hypertensive rats. Am J Physiol 254: H993-H1003, 1988.

RAY KP, FARROW S, DALY M, TALABOT F, SEARLE N: Induction of the E-selectin promoter by interleukin 1 and tumour necrosis factor alpha, and inhibition by glucocorticoids. Biochem J 328: 707-715, 1997.

REGECOVÁ V, KELLEROVÁ E: Effects of urban noise pollution on blood pressure and heart rate in preschool children. J Hypertens 13: 405-412, 1995.

REGECOVÁ V, KELLEROVÁ E: Ambulatory blood pressure monitoring in relation to daily routine activities (in Slovak). Cardiology Lett 24: 251-256, 2015.

REIS WL, GIUSTI-PAIVA A, VENTURA RR, MARGATHO LO, GOMES DA, ELIAS LL, ANTUNESRODRIGUES J: Central nitric oxide blocks vasopressin, oxytocin and atrial natriuretic peptide release and antidiuretic and natriuretic responses induced by central angiotensin II in conscious rats. Exp Physiol 92: 903-911, 2007.

REPOVÁ-BEDNÁROVÁ K, AZIRIOVÁ S, HRENÁK J, KRAJČÍROVIČOVÁ K, ADAMCOVÁ M, PAULIS L, SIMKO F: Effect of captopril and melatonin on fibrotic rebuilding of the aorta in 24 hour light-induced hypertension. Physiol Res 62 (Suppl 1): S135-S141, 2013.

RETTORI V, CANTEROS G, MCCANN SM: Interaction between NO and oxytocin: influence on LHRH release. Braz J Med Biol Res 30: 453-457, 1997.

RIESSELMANN A, BARON A, FREGLY MJ, VAN BERGEN P: Hypertension during chronic exposure to cold: comparison between Sprague-Dawley and Long-Evans strains. Can J Physiol Pharmacol 70: 701-708, 1992.

RIVIER C: Endogenous nitric oxide participates in the activation of the hypothalamic-pituitary-adrenal axis by noxious stimuli. Endocr J 2: 367-373, 1994.

RIVIER C: Role of gaseous neurotransmitters in the hypothalamic-pituitary-adrenal axis. Ann NY Acad Sci 933: 254-264, 2001.

ROGERS KM, BONAR CA, ESTRELLA JL, YANG S: Inhibitory effect of glucocorticoid on coronary artery endothelial function. Am J Physiol Heart Circ Physiol 283: H1922-H1928, 2002.

ROSENGREN A, HAWKEN S, OUNPUU S, SLIWA K, ZUBAID M, ALMAHMEED WA, BLACKETT KN, SITTHI-AMORN C, SATO H, YUSUF S; INTERHEART INVESTIGATORS: Association of psychosocial risk factors with risk of acute myocardial infarction in 11119 cases and 13648 controls from 52 countries (the INTERHEART study): case-control study. Lancet 364: 953-962, 2004. 
ROSSI NF, MALISZEWSKA-SCISLO M, CHEN H, BLACK SM, SHARMA S, RAVIKOV R, AUGUSTYNIAK RA: Neuronal nitric oxide synthase within paraventricular nucleus: blood pressure and baroreflex in two-kidney, one-clip hypertensive rats. Exp Physiol 95: 845-857, 2010.

ROZANSKI A, BAIREY CN, KRANTZ DS, FRIEDMAN J, RESSER KJ, MORELL M, HILTON-CHALFEN S, HESTRIN L, BIETENDORF J, BERMAN DS: Mental stress and the induction of silent myocardial ischemia in patients with coronary artery disease. $N$ Engl J Med 318: 1005-1012, 1988.

ROZANSKI A, BLUMENTHAL JA, KAPLAN J: Impact of psychological factors on the pathogenesis of cardiovascular disease and implications for therapy. Circulation 99: 2192-2217, 1999.

SAID MA, EL-GOHARY OA: Effect of noise stress on cardiovascular system in adult male albino rat: implication of stress hormones, endothelial dysfunction and oxidative stress. Gen Physiol Biophys 35: 371-377, 2016.

SALES AR, FERNANDES IA, ROCHA NG, COSTA LS, ROCHA HN, MATTOS JD, VIANNA LC, SILVA BM, NÓBREGA AC: Aerobic exercise acutely prevents the endothelial dysfunction induced by mental stress among subjects with metabolic syndrome: the role of shear rate. Am J Physiol Heart Circ Physiol 306: H963H971, 2014.

SÄLLSTRÖM J, CARLSTRÖM M, JENSEN BL, SKØTT O, BROWN RD, PERSSON AE: Neuronal nitric oxide synthase-deficient mice have impaired renin release but normal blood pressure. Am J Hypertens 21: 111-116, 2008.

SANDER M, VICTOR RG: Neural mechanisms in nitric-oxide-deficient hypertension. Curr Opin Nephrol Hypertens 8: 61-73, 1999 .

SANDER M, HANSEN PG, VICTOR RG: Sympathetically mediated hypertension caused by chronic inhibition of nitric oxide. Hypertension 26: 691-695, 1995.

SANDERS BJ, KNARDAHL S, JOHNSON AK: Lesions of the anteroventral third ventricle and development of stressinduce hypertension in the borderline hypertensive rat. Hypertension 13: 817-821, 1989.

SANDERS BJ, LAWLER JE: The borderline hypertensive rat (BHR) as a model for environmentally-induced hypertension: a review and update. Neurosci Biobehav Rev 16: 207-217, 1992.

ŠARENAC O, LOZIĆ M, DRAKULIĆ S, BAJIĆ D, PATON JF, MURPHY D, JAPUNDŽIĆ-ŽIGON N: Autonomic mechanisms underpinning the stress response in borderline hypertensive rats. Exp Physiol 96: 574-589, 2011.

SARUTA T: Mechanism of glucocorticoid-induced hypertension. Hypertens Res 19: 1-8, 1996.

SCHWARTZ BG, FRENCH WJ, MAYEDA GS, BURSTEIN S, ECONOMIDES C, BHANDARI AK, CANNOM DS, KLONER RA: Emotional stressors trigger cardiovascular events. Int J Clin Pract 66: 631-639, 2012.

SCHWARZ P, DIEM R, DUN NJ, FÖRSTERMANN U: Endogenous and exogenous nitric oxide inhibits norepinephrine release from rat heart sympathetic nerves. Circ Res 77: 841-848, 1995.

SELYE H: A syndrome produced by diverse nocuous agents. Nature 138: P32, 1936.

SELYE H: Stress and the general adaptation syndrome. Br Med J 1: 1383-1392, 1950.

SHAPOVAL LN, SAGACH VF, POBEGAILO LS: Nitric oxide influences ventrolateral medullary mechanisms of vasomotor control in the cat. Neurosci Lett 132: 47-50, 1991.

SHIMOKAWA H, YASUTAKE H, FUJII K, OWADA MK, NAKAIKE R, FUKUMOTO Y, TAKAYANAGI T, NAGAO T, EGASHIRA K, FUJISHIMA M, TAKESHITA A: The importance of the hyperpolarizing mechanism increases as the vessel size decreases in endothelium-dependent relaxations in rat mesenteric circulation. J Cardiovasc Pharmacol 28: 703-711, 1996.

SIMKO F, PECHANOVA O, PELOUCH V, KRAJCIROVICOVA K, CELEC P, PALFFY R, BEDNAROVA K, VRANKOVA S, ADAMCOVA M, PAULIS L: Continuous light and L-NAME-induced left ventricular remodelling: different protection with melatonin and captopril. J Hypertens 28 (Suppl 1): S13-S18, 2010.

SIMKO F, PECHANOVA O, REPOVA BEDNAROVA K, KRAJCIROVICOVA K, CELEC P, KAMODYOVA N, ZORAD S, KUCHARSKA J, GVOZDJAKOVA A, ADAMCOVA M, PAULIS L: Hypertension and cardiovascular remodelling in rats exposed to continuous light: protection by ACE-inhibition and melatonin. Mediators Inflamm 2014: 703175, 2014.

SIMMONS WW, UNGUREANU-LONGROIS D, SMITH GK, SMITH TW, KELLY RA: Glucocorticoids regulate inducible nitric oxide synthase by inhibiting tetrahydrobiopterin synthesis and L-arginine transport. $J$ Biol Chem 271: 23928-23937, 1996. 
SIVONOVÁ M, ZITNANOVÁ I, HLINCÍKOVÁ L, SKODÁCEK I, TREBATICKÁ J, DURACKOVÁ Z: Oxidative stress in university students during examinations. Stress 7: 183-188, 2004.

SKANTZE HB, KAPLAN J, PETTERSSON K, MANUCK S, BLOMQVIST N, KYES R, WILLIAMS K, BONDJERS G: Psychosocial stress causes endothelial injury in cynomolgus monkeys via beta1-adrenoceptor activation. Atherosclerosis 136: 153-161, 1998.

SLEZAK P, PUZSEROVA A, BALIS P, SESTAKOVA N, MAJZUNOVA M, DOVINOVA I, KLUKNAVSKY M, BERNATOVA I: Genotype-related effect of crowding stress on blood pressure and vascular function in young female rats. Biomed Res Int 2014: 413629, 2014.

SMIEŠKO V, JOHNSON PC: The arterial lumen is controlled by flow-related shear stress. News Physiol Sci 8: 34-38, 1993.

SMIESKO V, KOZÍK J, DOLEZEL S: Role of endothelium in the control of arterial diameter by blood flow. Blood Vessels 22: 247-251, 1985.

SPARRENBERGER F, FUCHS SC, MOREIRA LB, FUCHS FD: Stressful life events and current psychological distress are associated with self-reported hypertension but not with true hypertension: results from a crosssectional population-based study. BMC Public Health 8: 357, 2008.

SPIEKER LE, HÜRLIMANN D, RUSCHITZKA F, CORTI R, ENSELEIT F, SHAW S, HAYOZ D, DEANFIELD JE, LÜSCHER TF, NOLL G: Mental stress induces prolonged endothelial dysfunction via endothelin-A receptors. Circulation 105: 2817-2820, 2002.

SPRUILL TM: Chronic psychosocial stress and hypertension. Curr Hypertens Rep 12: 10-16, 2010.

SRIRAM K, LAUGHLIN JG, RANGAMANI P, TARTAKOVSKY DM: Shear-induced nitric oxide production by endothelial cells. Biophys $J$ 111: 208-221, 2016.

STEFANO GB, FRICCHIONE GL, ESCH T: Relaxation: Molecular and physiological significance. Med Sci Monit 12: HY21-HY31, 2006.

STEINERT JR, CHERNOVA T, FORSYTHE ID: Nitric oxide signaling in brain function, dysfunction, and dementia. Neuroscientist 16: 435-452, 2010.

STEPTOE A, BRYDON L: Emotional triggering of cardiac events. Neurosci Biobehav Rev 33: 63-70, 2009.

STEPTOE A, KIVIMÄKI M: Stress and cardiovascular disease: an update on current knowledge. Annu Rev Public Health 34: 337-354, 2013.

STERN JE, LUDWIG M: NO inhibits supraoptic oxytocin and vasopressin neurons via activation of GABAergic synaptic inputs. Am J Physiol Regul Integr Comp Physiol 280: R1815-R1822, 2001.

STRAWN WB, BONDJERS G, KAPLAN JR, MANUCK SB, SCHWENKE DC, HANSSON GK, SHIVELY CA, CLARKSON TB: Endothelial dysfunction in response to psychosocial stress in monkeys. Circ Res 68: 12701279, 1991.

STRUZKOVA K, STOURAC P, KANOVSKY J, KRIKAVA I, TOUKALKOVA M, SEVCIK P: An unusual reason for severe bradycardia leading to cardiac arrest during general anaesthesia: a case report. Biomed Pap Med Fac Univ Palacky Olomouc Czech Repub 158: 659-661, 2014.

SZIJGYARTO IC, POITRAS VJ, GURD BJ, PYKE KE: Acute psychological and physical stress transiently enhances brachial artery flow-mediated dilation stimulated by exercise-induced increases in shear stress. Appl Physiol Nutr Metab 39: 927-936, 2014.

TADDEI S, VIRDIS A, GHIADONI L, MAGAGNA A, SALVETTI A: Vitamin C improves endothelium-dependent vasodilation by restoring nitric oxide activity in essential hypertension. Circulation 97: 2222-2229, 1998.

TAKAKI J: Associations of job stress indicators with oxidative biomarkers in Japanese men and women. Int J Environ Res Public Health 10: 6662-6671, 2013.

THIBONNIER M, CONARTY DM, PRESTON JA, PLESNICHER CL, DWEIK RA, ERZURUM SC: Human vascular endothelial cells express oxytocin receptors. Endocrinology 140: 1301-1309, 1999.

TIMIO M, SARONIO P, VERDURA C, SCHIAROLI M, TIMIO F, MONARCA C: A link between psychosocial factors and blood pressure trend in women. Physiol Behav 73: 359-363, 2001.

TODA N, NAKANISHI-TODA M: How mental stress affects endothelial function. Pflugers Arch 462: 779-794, 2011.

TÖRÖK J: Participation of nitric oxide in different models of experimental hypertension. Physiol Res 57: 813-825, 2008. 
TÖRÖK J, GEROVA M: Vascular responses after long-term inhibition of nitric oxide synthesis in newborn dogs. Physiol Res 45: 323-328, 1996.

TORRES M, CEBALLOS G, RUBIO R: Possible role of nitric oxide in catecholamine secretion by chromaffin cells in the presence and absence of cultured endothelial cells. J Neurochem 63: 988-996, 1994.

TSUCHIYA T, KISHIMOTO J, KOYAMA J, OZAWA T: Modulatory effect of L-NAME, a specific nitric oxide synthase (NOS) inhibitor, on stress-induced changes in plasma adrenocorticotropic hormone (ACTH) and corticosterone levels in rats: physiological significance of stress-induced NOS activation in hypothalamicpituitary-adrenal axis. Brain Res 776: 68-74, 1997.

TSUTSUI M, SHIMOKAWA H, OTSUJI Y, YANAGIHARA N: Pathophysiological relevance of NO signaling in the cardiovascular system: novel insight from mice lacking all NO synthases. Pharmacol Ther 128: 499-508, 2010.

TUCKER DC, HUNT RA: Effects of long-term air jet noise and dietary sodium chloride in borderline hypertensive rats. Hypertension 22: 527-534, 1993.

TURECKI G, MEANEY MJ: Effects of the social environment and stress on glucocorticoid receptor gene methylation: a systematic review. Biol Psychiatry 79: 87-96, 2016.

ULLIAN ME: The role of corticosteroids in the regulation of vascular tone. Cardiovasc Res 41: 55-64, 1999.

VANHATALO S, SOINILA S: Nitric oxide synthase in the hypothalamo-pituitary pathways. $J$ Chem Neuroanat 8: 165-173, 1995.

VANHOUTTE PM: Endothelium-dependent contractions in hypertension: when prostacyclin becomes ugly. Hypertension 57: 526-531, 2011.

VARGAS F, MORENO JM, WANGENSTEEN R, RODRÍGUEZ-GÓMEZ I, GARCÍA-ESTAÑ J: The endocrine system in chronic nitric oxide deficiency. Eur J Endocrinol 156: 1-12, 2007.

VILLANUEVA C, GIULIVI C: Subcellular and cellular locations of nitric oxide synthase isoforms as determinants of health and disease. Free Radic Biol Med 49: 307-316, 2010.

VIRDIS A, GHIADONI L, TADDEI S: Human endothelial dysfunction: EDCFs. Pflugers Arch 459: 1015-1023, 2010.

VÍTEČEK J, LOJEK A, VALACCHI G, KUBALA L: Arginine-based inhibitors of nitric oxide synthase: therapeutic potential and challenges. Mediators Inflamm 2012: 318087, 2012.

WALKER BR, EDWARDS CR: New mechanisms for corticosteroid-induced hypertension. Br Med Bull 50: 342-355, 1994.

WALLERATH T, WITTE K, SCHAFER SC, SCHWARZ PM, PRELLWITZ W, WOHLFART P, KLEINERT H, LEHR HA, LEMMER B, FORSTERMANN U: Down-regulation of the expression of endothelial NO synthase is likely to contribute to glucocorticoid-mediated hypertension. Proc Natl Acad Sci U S A 96: 13357-13362, 1999.

WALLERATH T, GÖDECKE A, MOLOJAVYI A, LI H, SCHRADER J, FÖRSTERMANN U: Dexamethasone lacks effect on blood pressure in mice with a disrupted endothelial NO synthase gene. Nitric Oxide 10: 36-41, 2004.

WANGENSTEEN R, SAINZ J, RODRÍGUEZ-GOMEZ I, MORENO JM, OSUNA A, VARGAS F: Chronic blockade of neuronal nitric oxide synthase does not affect long-term control of blood pressure in normal, saline-drinking or deoxycorticosterone-treated rats. Exp Physiol 88: 243-250, 2003.

WEBB RC, VANDER AJ, HENRY JP: Increased vasodilator responses to acetylcholine in psychosocial hypertensive mice. Hypertension 9: 268-276, 1987.

WHF, 2015: http://www.world-heart-federation.org/cardiovascular-health/cardiovascular-disease-risk-factors/stress/

WHO, 2015: http://www.who.int/mediacentre/factsheets/fs317/en/

WILBERT-LAMPEN U, LEISTNER D, GREVEN S, POHL T, SPER S, VÖLKER C, GÜTHLIN D, PLASSE A, KNEZ A, KÜCHENHOFF H, STEINBECK G: Cardiovascular events during World Cup soccer. $N$ Engl J Med 358: 475-483, 2008.

WILLIAMS JK, VITA JA, MANUCK SB, SELWYN AP, KAPLAN JR: Psychosocial factors impair vascular responses of coronary arteries. Circulation 84: 2146-2153, 1991.

WILLIAMS JK, KAPLAN JR, MANUCK SB: Effects of psychosocial stress on endothelium-mediated dilation of atherosclerotic arteries in cynomolgus monkeys. $J$ Clin Invest 92: 1819-1823, 1993.

WILLICH SN, LÖWEL H, LEWIS M, HÖRMANN A, ARNTZ HR, KEIL U: Weekly variation of acute myocardial infarction. Increased Monday risk in the working population. Circulation 90: 87-93, 1994. 
WITTSTEIN IS, THIEMANN DR, LIMA JA, BAUGHMAN KL, SCHULMAN SP, GERSTENBLITH G, WU KC, RADE JJ, BIVALACQUA TJ, CHAMPION HC: Neurohumoral features of myocardial stunning due to sudden emotional stress. N Engl J Med 352: 539-548, 2005.

WSÓŁ A, CUDNOCH-JEDRZEJEWSKA A, SZCZEPANSKA-SADOWSKA E, KOWALEWSKI S, PUCHALSKA L: Oxytocin in the cardiovascular responses to stress. J Physiol Pharmacol 59 (Suppl 8): 123-127, 2008.

WSÓŁ A, CUDNOCH-JEDRZEJEWSKA A, SZCZEPANSKA-SADOWSKA E, KOWALEWSKI S, DOBRUCH J: Central oxytocin modulation of acute stress-induced cardiovascular responses after myocardial infarction in the rat. Stress 12: 517-525, 2009.

WU ZT, REN CZ, YANG YH, ZHANG RW, SUN JC, WANG YK, SU DF, WANG WZ: The PI3K signalingmediated nitric oxide contributes to cardiovascular effects of angiotensin-(1-7) in the nucleus tractus solitarii of rats. Nitric Oxide 52: 56-65, 2016.

Y-HASSAN S, FELDT K, STÅLBERG M: A missed penalty kick triggered coronary death in the husband and broken heart syndrome in the wife. Am J Cardiol 116: 1639-1642, 2015.

ZAFIR A, BANU N: Antioxidant potential of fluoxetine in comparison to Curcuma longa in restraint-stressed rats. Eur J Pharmacol 572: 23-31, 2007.

ZAFIR A, BANU N: Modulation of in vivo oxidative status by exogenous corticosterone and restraint stress in rats. Stress 12: 167-177, 2009.

ZANCHI A, SCHAAD NC, OSTERHELD MC, GROUZMANN E, NUSSBERGER J, BRUNNER HR, WAEBER B: Effects of chronic NO synthase inhibition in rats on renin-angiotensin system and sympathetic nervous system. Am J Physiol 268: H2267-H2273, 1995.

ZEMANČÍKOVÁ A, TÖRÖK J: Comparison of cardiovascular characteristics in normotensive and hypertensive rat strains. Indian J Physiol Pharmacol 59: 361-368, 2015.

ZHANG H, DELLSPERGER KC, ZHANG C: The link between metabolic abnormalities and endothelial dysfunction in type 2 diabetes: an update. Basic Res Cardiol 107: 237, 2012.

ZHANG K, PATEL KP: Effect of nitric oxide within the paraventricular nucleus on renal sympathetic nerve discharge: role of GABA. Am J Physiol 275: R728-R734, 1998.

ZHOU QG, ZHU LJ, CHEN C, WU HY, LUO CX, CHANG L, ZHU DY: Hippocampal neuronal nitric oxide synthase mediates the stress-related depressive behaviors of glucocorticoids by downregulating glucocorticoid receptor. J Neurosci 31: 7579-7590, 2011.

ZHOU YB, SUN HJ, CHEN D, LIU TY, HAN Y, WANG JJ, TANG CS, KANG YM, ZHU GQ: Intermedin in paraventricular nucleus attenuates sympathetic activity and blood pressure via nitric oxide in hypertensive rats. Hypertension 63: 330-337, 2014.

ZHU LJ, LIU MY, LI H, LIU X, CHEN C, HAN Z, WU HY, JING X, ZHOU HH, SUH H, ZHU DY, ZHOU QG: The different roles of glucocorticoids in the hippocampus and hypothalamus in chronic stress-induced HPA axis hyperactivity. PLoS One 9: e97689, 2014.

ZICHA J, KUNES J: Ontogenetic aspects of hypertension development: analysis in the rat. Physiol Rev 79: 1227-1282, 1999.

ZICHA J, DOBESOVÁ Z, KUNES J: Antihypertensive mechanisms of chronic captopril or N-acetylcysteine treatment in L-NAME hypertensive rats. Hypertens Res 29: 1021-1027, 2006.

ZICHA J, KUNES J, VRANKOVÁ S, JENDEKOVÁ L, DOBESOVÁ Z, PINTÉROVÁ M, PECHÁNOVÁ O: Influence of pertussis toxin pretreatment on the development of L-NAME-induced hypertension. Physiol Res 58: 751-755, 2009.

ZICHA J, DOBEŠOVÁ Z, BEHULIAK M, PINTÉROVÁ M, KUNEŠ J, VANĚČKOVÁ I: Nifedipine-sensitive blood pressure component in hypertensive models characterized by high activity of either sympathetic nervous system or renin-angiotensin system. Physiol Res 63: 13-26, 2014. 